Prepared in cooperation with the California Department of Water Resources, National Park Service, and Pepperwood Preserve

\title{
Soil Moisture Datasets at Five Sites in the Central Sierra Nevada and Northern Coast Ranges, California
}
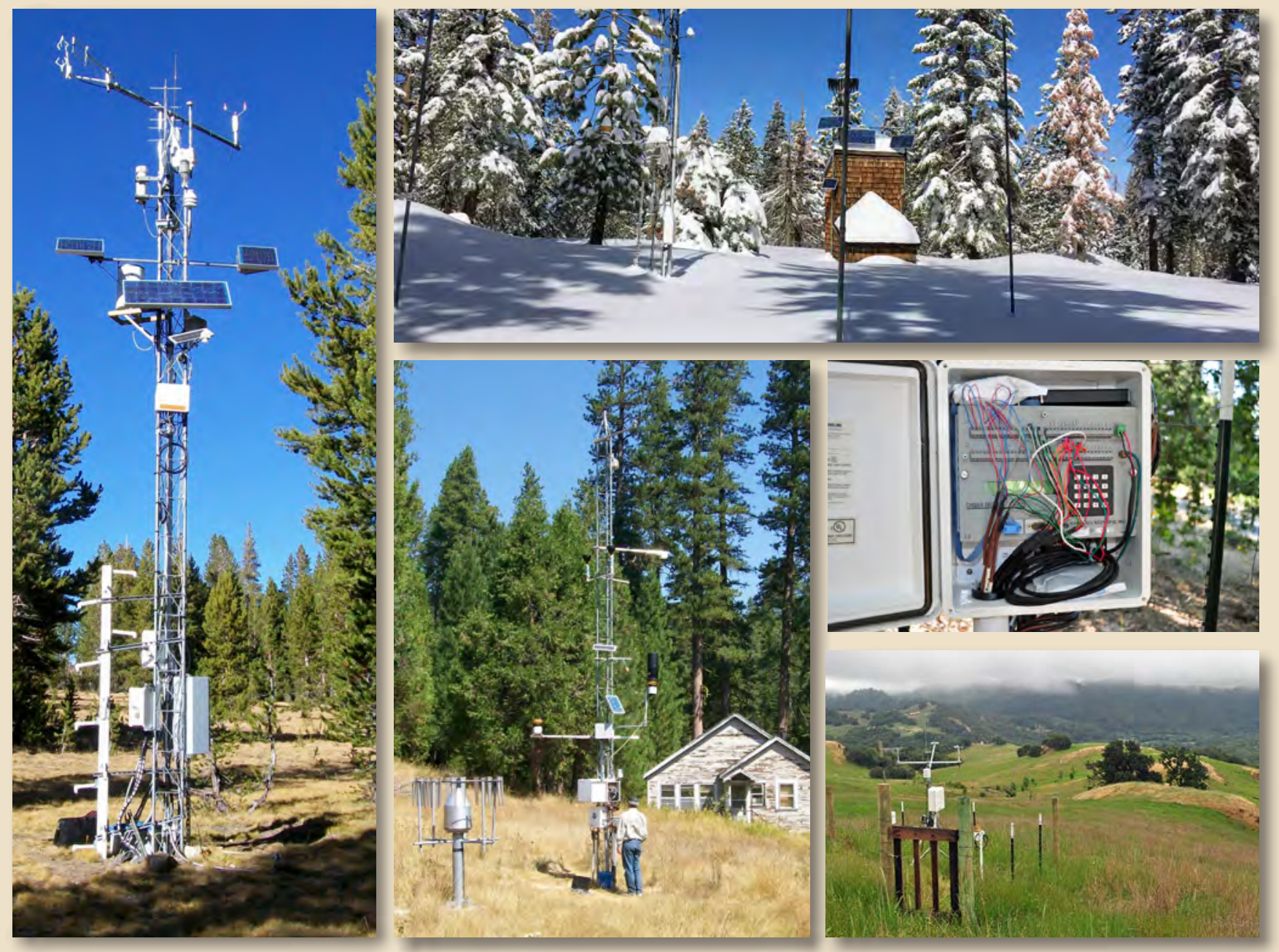

Data Series 1083

U.S. Department of the Interior U.S. Geological Survey 


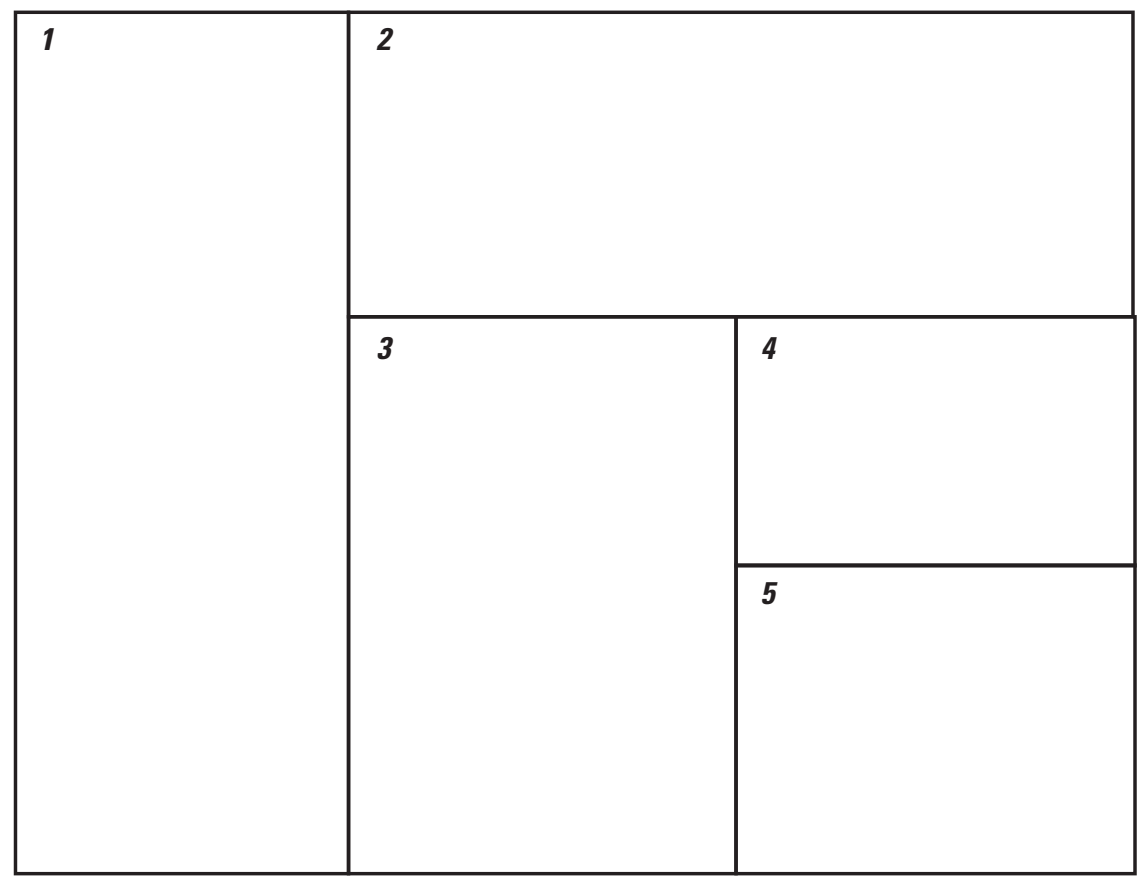

Cover. 1. Central Sierra Nevada, Yosemite National Park site, Dana Meadows. (Photograph taken by Frank Anderson, for U.S. Geological Survey.)

2. Central Sierra Nevada, Yosemite National Park site, Gin Flat. (Photograph courtesy of Harrison Forester, National Park Service, used with permission.)

3. Central Sierra Nevada, Yosemite National Park site, Hodgdon Meadows. (Photograph taken by Frank Anderson, for U.S. Geological Survey.)

4. Northern Coast Ranges, Pepperwood Preserve site, Oak. (Photograph taken by Frank Anderson, for U.S. Geological Survey.)

5. Northern Coast Ranges, Pepperwood Preserve site, Grass. (Photograph taken by Frank Anderson, for U.S. Geological Survey.) 


\section{Soil Moisture Datasets at Five Sites in the Central Sierra Nevada and Northern Coast Ranges, California}

By Michelle A. Stern, Frank A. Anderson, Lorraine E. Flint, and Alan L. Flint

Prepared in cooperation with the California Department of Water Resources, National Park Service, and Pepperwood Preserve

Data Series 1083 


\title{
U.S. Department of the Interior \\ RYAN K. ZINKE, Secretary
}

\section{U.S. Geological Survey \\ William H. Werkheiser, Deputy Director exercising the authority of the Director}

\author{
U.S. Geological Survey, Reston, Virginia: 2018
}

For more information on the USGS - the Federal source for science about the Earth, its natural and living resources, natural hazards, and the environment-visit https://www.usgs.gov or call 1-888-ASK-USGS.

For an overview of USGS information products, including maps, imagery, and publications,

visit https://store.usgs.gov.

Any use of trade, firm, or product names is for descriptive purposes only and does not imply endorsement by the U.S. Government.

Although this information product, for the most part, is in the public domain, it also may contain copyrighted materials as noted in the text. Permission to reproduce copyrighted items must be secured from the copyright owner.

Suggested citation:

Stern, M.A., Anderson, F.A., Flint, L.E., and Flint, A.L., 2018, Soil moisture datasets at five sites in the central Sierra Nevada and northern Coast Ranges, California: U.S. Geological Survey Data Series 1083, 23 p., https://doi.org/10.3133/ds1083.

ISSN 2327-638X (online) 


\section{Acknowledgments}

The authors thank Frank Gerhke (California Department of Water Resources) for site and equipment maintenance, technical expertise, data collection, and troubleshooting; James Roche (National Park Service) and Michael Dettinger (U.S. Geological Survey) for facilitating the research in Yosemite National Park and leading scientific discussions that led to the inception of the Yosemite sites; and David Anderson and Celeste Dodge (Pepperwood Preserve) for their technical expertise, data collection, data analysis, and troubleshooting.

\section{Contents}

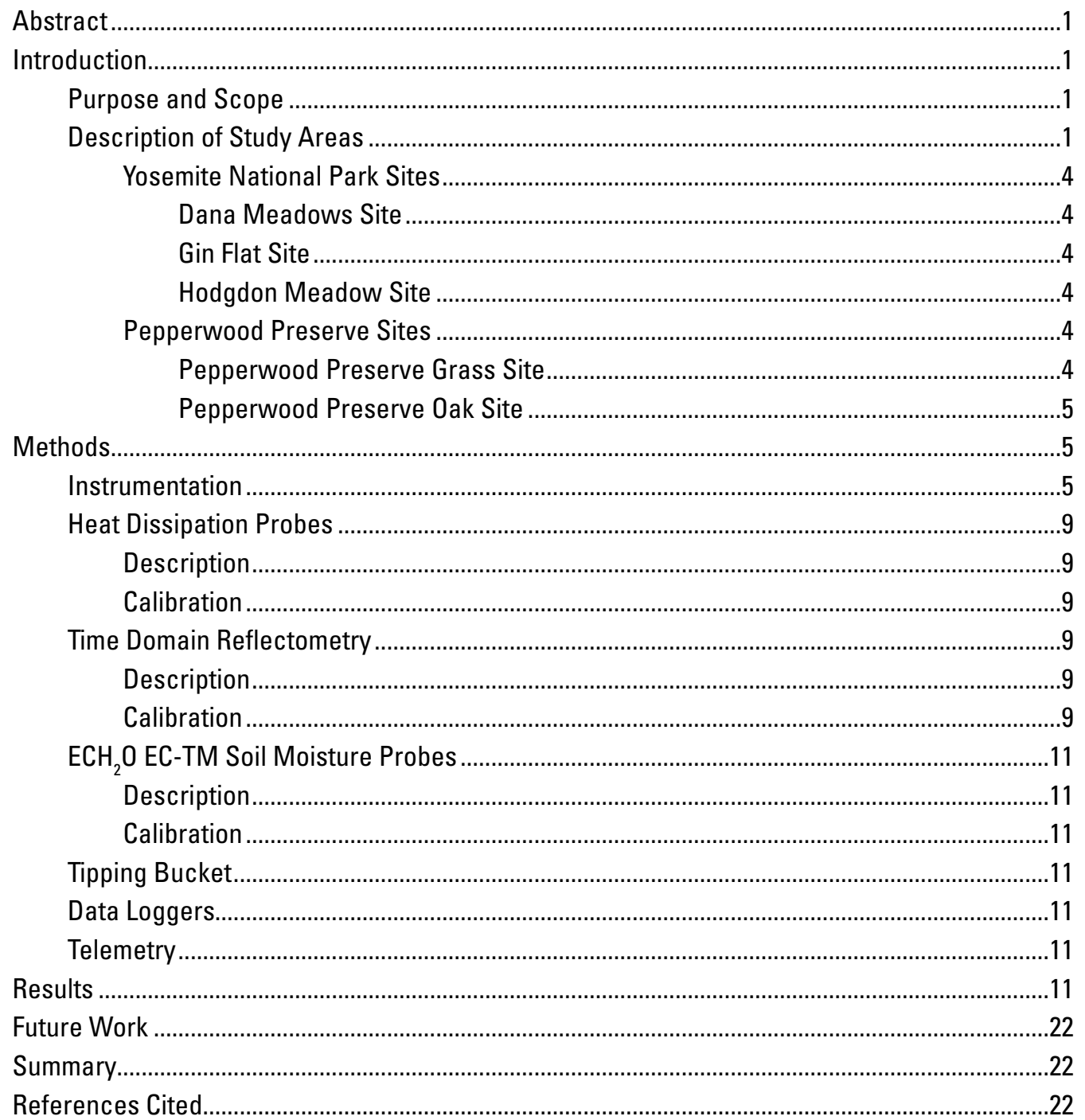




\section{Figures}

1. Map showing location of three sites within Yosemite National Park:

Dana Meadows, Gin Flat, and Hodgdon Meadow

2. Aerial photograph showing location of the two Pepperwood Preserve sites:

Grass and Oak

3. Photograph showing Pepperwood Preserve Grass site

4. Photograph showing Pepperwood Preserve Oak site

5. Graph showing soil water matric potential for the Dana Meadows site at four depths

6. Graph showing volumetric soil water content for the Dana Meadows site at four depths

7. Graph showing total soil water content for the Dana Meadows site to the depth of 79 centimeters.

8. Graph showing soil temperature for the Dana Meadows site at four depths.

9. Graph showing soil water matric potential for the Gin Flat site at three depths .............14

10. Graph showing volumetric soil water content for the Gin Flat site at three depths .......14

11. Graph showing total soil water content for the Gin Flat site to a depth of 72 centimeters

12. Graph showing soil temperature for the Gin Flat site at three depths

13. Graph showing soil water matric potential for the Hodgdon Meadow site at four depths

14. Graph showing volumetric soil water content for the Hodgdon Meadow site at three depths

15. Graph showing total soil water content for the Hodgdon Meadow site to a depth of 50 centimeters

16. Graph showing soil temperature for the Hodgdon Meadow site at four depths

17. Graph showing soil water matric potential for the Pepperwood Preserve Grass site at four depths

18. Graph showing volumetric soil water content for the Pepperwood Preserve Grass site at four depths

19. Graph showing total soil water content for the Pepperwood Preserve Grass site to the depth of 90 centimeters

20. Graph showing soil temperature for the Pepperwood Preserve Grass site at four depths

21. Graph showing soil water matric potential for the Pepperwood Preserve Oak site at four depths.

22. Graph showing volumetric soil water content for the Pepperwood Preserve Oak site at four depths.

23. Graph showing total soil water content for the Pepperwood Preserve Oak site to the depth of 70 centimeters.

24. Graph showing soil temperature for the Pepperwood Preserve Oak site at four depths 


\section{Tables}

1. Soil instrumentation at the Dana Meadows site with soil depths, serial numbers, and deployment duration of the instrumentation

2. Logging instrumentation at the Dana Meadows site, serial number, and deployment duration of the instrumentation.

3. Soil instrumentation at the Gin Flat site with soil depths, serial numbers, soil observations, and deployment duration of the instrumentation.

4. Logging instrumentation at the Gin Flat site, serial number, and deployment duration of the instrumentation.

5. Soil instrumentation at the Hodgdon Meadow site with soil depths, serial numbers, soil observations, and deployment duration of the instrumentation.......7

6. Logging and instrumentation at the Hodgdon Meadow site, serial number, and deployment duration of the instrumentation.

7. Soil instrumentation at the Pepperwood Preserve Grass site with soil depths, serial numbers, soil observations, bulk density, and deployment duration of the instrumentation.

8. Logging and telemetry instrumentation and solar-power system at the Pepperwood Preserve Grass site and deployment duration of the instrumentation........8

9. Soil instrumentation at the Pepperwood Preserve Oak site with soil depths, serial number, soil observations, bulk density, and duration of instrumentation

10. Logging and telemetry instrumentation and solar-power system at the Pepperwood Preserve Oak site and duration of instrumentation...

11. Site name, depth, slope, and intercept for Pepperwood Preserve Grass and Oak sites used in time domain reflectometry probe calibrations.

12. Comma separated values file for the Dana Meadows site including hourly time series of soil temperature, soil water matric potential, volumetric water content, and total soil water content. external csv file

13. Comma separated values file for the Gin Flat site including hourly time series of soil temperature, soil water matric potential, volumetric water content, and total soil water content. external csv file

14. Comma separated values file for Hodgdon Meadows including hourly time series of soil temperature, soil water matric potential, volumetric water content and total soil water content external csv file

15. Comma separated values file for the Pepperwood Preserve Grass site including hourly time series of soil temperature, soil water matric potential, volumetric water content, and total soil water content. external csv file

16. Comma separated values file for the Pepperwood Preserve Oak site including hourly time series of soil temperature, soil water matric potential, volumetric water content, and total soil water content. external csv file 


\section{Conversion Factors}

International System of Units to U.S. customary units

\begin{tabular}{lcl}
\hline \multicolumn{1}{c}{ Multiply } & By & \multicolumn{1}{c}{ To obtain } \\
\hline centimeter $(\mathrm{cm})$ & Length & inch (in.) \\
millimeter $(\mathrm{mm})$ & 0.3937 & inch (in.) \\
meter $(\mathrm{m})$ & 0.03937 & foot $(\mathrm{ft})$ \\
kilometer $(\mathrm{km})$ & 3.281 & mile $(\mathrm{mi})$ \\
\hline & 0.6214 & \\
\hline square kilometer $\left(\mathrm{km}^{2}\right)$ & Area & square mile $\left(\mathrm{mi}^{2}\right)$ \\
\hline & 0.3861 & cubic inch $\left(\mathrm{in}^{3}\right)$ \\
\hline cubic centimeter $\left(\mathrm{cm}^{3}\right)$ & Volume & \\
\hline & 0.06102 & atmosphere, $\mathrm{standard}(\mathrm{atm})$ \\
\hline megapascal $(\mathrm{MPa})$ & Pressure & bar \\
\hline megapascal $(\mathrm{MPa})$ & 0.000009869 & pound per cubic foot $\left(\mathrm{lb} / \mathrm{ft}^{3}\right)$ \\
\hline
\end{tabular}

Temperature in degrees Celsius $\left({ }^{\circ} \mathrm{C}\right)$ may be converted to degrees Fahrenheit $\left({ }^{\circ} \mathrm{F}\right)$ as

$$
{ }^{\circ} \mathrm{F}=\left(1.8 \times{ }^{\circ} \mathrm{C}\right)+32 .
$$

\section{Datum}

Horizontal coordinate information is referenced to the North American Datum of 1983 (NAD 83).

Vertical coordinate information is referenced to the National Geodetic Vertical Datum of 1929 (NGVD 29). 


\section{Abbreviations}

$\begin{array}{ll}\text { CDEC } & \text { California Data Exchange Center } \\ \text { CS } & \text { Campbell Scientific } \\ \text { csV } & \text { comma separated values } \\ \text { EC-TM } & \text { ECH }_{2} \text { O EC-TM soil moisture probe } \\ \text { ERY } & \text { Ellery Lake } \\ \text { Grass } & \text { grassland ecosystem } \\ \text { GIN } & \text { Gin Flat } \\ \text { HDG } & \text { Hodgdon Meadow } \\ \text { HDP } & \text { heat dissipation probe } \\ \text { MHz } & \text { megahertz } \\ \text { NTN } & \text { National Trends Network } \\ \text { Oak } & \text { oak woodlands ecosystem } \\ \text { TDR } & \text { time domain reflectometry } \\ \text { TUM } & \text { Tuolumne Meadows } \\ \text { USGS } & \text { U.S. Geological Survey } \\ \text { VWC } & \text { volumetric water content }\end{array}$




\title{
Soil Moisture Datasets at Five Sites in the Central Sierra Nevada and Northern Coast Ranges, California
}

\author{
By Michelle A. Stern, Frank A. Anderson, Lorraine E. Flint, and Alan L. Flint
}

\begin{abstract}
In situ soil moisture datasets are important inputs used to calibrate and validate watershed, regional, or statewide modeled and satellite-based soil moisture estimates. The soil moisture dataset presented in this report includes hourly time series of the following: soil temperature, volumetric water content, water potential, and total soil water content. Data were collected by the U.S. Geological Survey at five locations in California: three sites in the central Sierra Nevada and two sites in the northern Coast Ranges. This report provides a description of each of the study areas, procedures and equipment used, processing steps, and time series data from each site in the form of comma-separated values (.csv) tables.
\end{abstract}

\section{Introduction}

Long-term in situ soil moisture datasets are required to improve the understanding of watershed responses to climate variability and are important inputs used to calibrate and validate watershed, regional, and statewide modeled and satellite-based soil moisture estimates. Soil moisture and temperature instrumentation were installed at each of five monitoring sites. Data from these sites can help gain an understanding of soil moisture processes in two localities within California's Mediterranean climate: the central Sierra Nevada, dominated by high elevation winter snow and persistent snowpack, and the northern Coast Ranges, with abundant fog.

The soil moisture dataset described in this report contains hourly time series of the following: soil temperature, volumetric water content, soil water matric potential, and total soil water content. Data were collected by the U.S. Geological Survey (USGS) in cooperation with the California Department of Water Resources, National Park Service, and Pepperwood Preserve at five locations in California: three sites in the central Sierra Nevada and two sites in the northern Coast Ranges. Three central Sierra Nevada sites are within Yosemite National Park (fig. 1) and were installed to help understand snowmelt processes in a range of soil conditions and elevations (about 1,400-3,000 meters, m, NGVD 29). Soil probes installed at these sites extend beyond the surficial soil layer to bedrock or near bedrock when possible, which can provide information about the total soil profile, improving upon soil moisture probes that do not extend deeper than the top 10 centimeters $(\mathrm{cm})$ of the soil profile.

The two northern Coast Ranges sites are within the Pepperwood Preserve, about 20 kilometers $(\mathrm{km})$ northeast of Santa Rosa, California (fig. 2). The Pepperwood Preserve sites were developed as long-term sentinel sites for studying biodiversity in the two dominant vegetation types of the area: grasslands and oak woodlands.

\section{Purpose and Scope}

This report describes soil moisture and temperature data from five study sites in the central Sierra Nevada (Yosemite National Park) and the northern Coast Ranges (Pepperwood Preserve) collected for the purpose of understanding hydrologic, climatic, and biologic soil moisture dynamics in snow-dominated watersheds and coastal fog-dominated watersheds. This dataset will contribute long-term hourly time-series soil moisture and temperature data to help improve the understanding of the soil's response to climate.

\section{Description of Study Areas}

The two study areas in the Sierra Nevada and northern Coast Ranges represent geologic and hydroclimatic contrasts that were selected for the purpose of understanding hydrologic, climatic, and biologic soil moisture dynamics in snow-dominated watersheds and coastal fog-dominated watersheds. The Yosemite National Park sites in the Sierra Nevada had soil moisture and temperature sensors installed to study the influence of elevation changes and snow pack on soil properties in the central Sierra Nevada. The Pepperwood Preserve monitoring sites in the northern Coast Ranges had soil moisture and temperature sensors installed to study the interaction of rain, moisture from fog, general weather conditions, and the effect that grassland and oak woodland environments can have on soil conditions and biodiversity. 


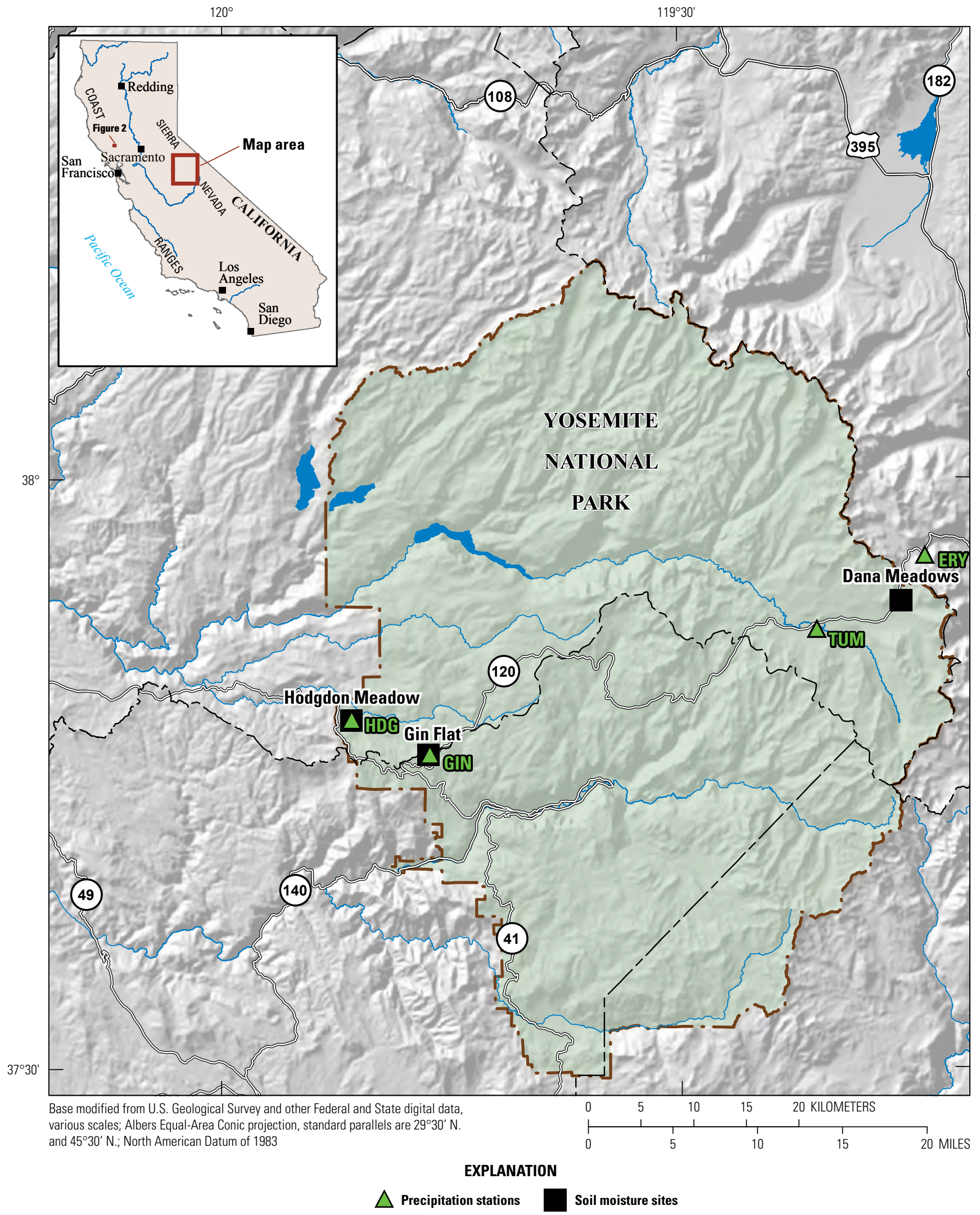

Figure 1. Location of three sites within Yosemite National Park: Dana Meadows, Gin Flat, and Hodgdon Meadow. 


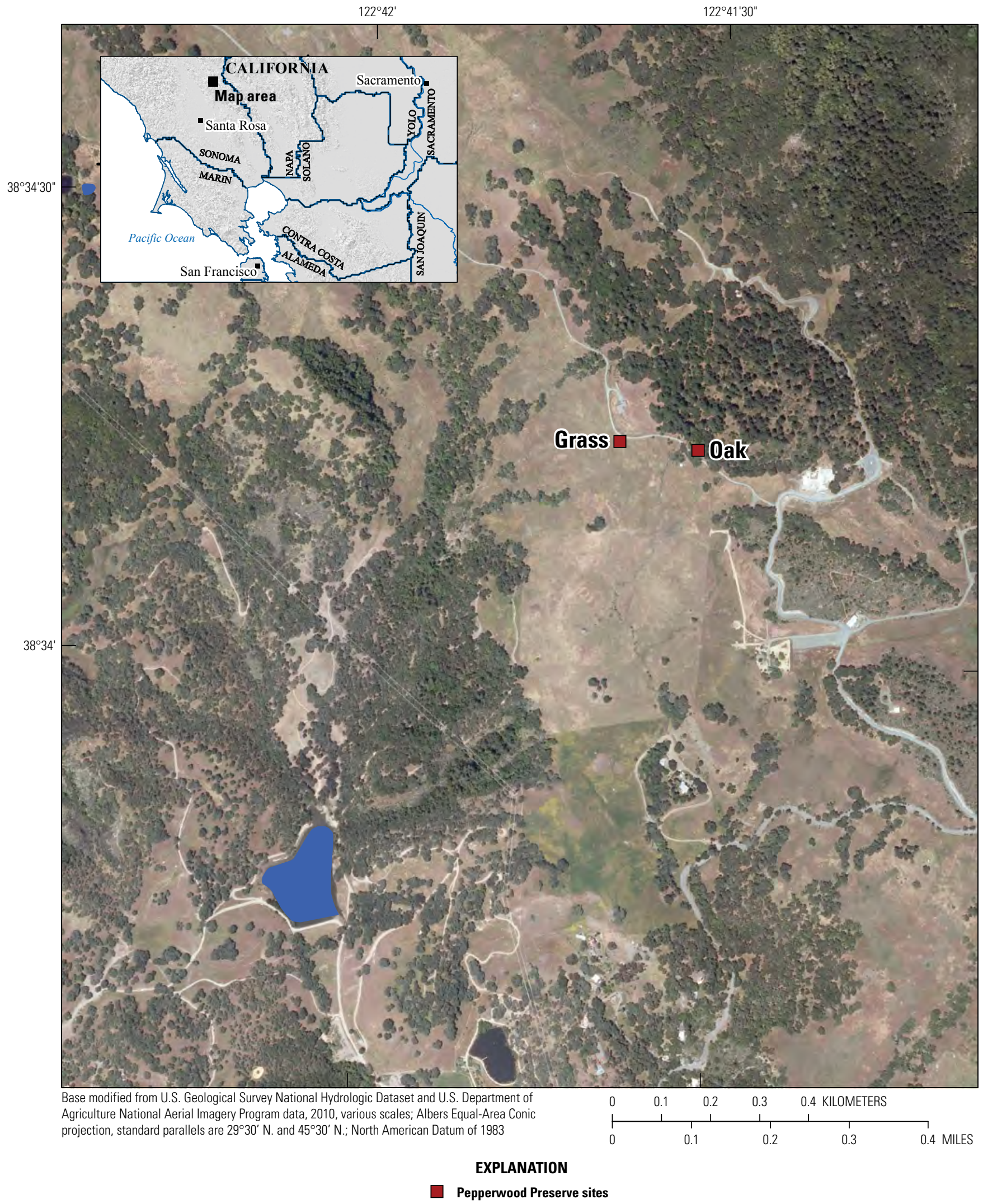

Figure 2. Location of the two Pepperwood Preserve sites: Grass and Oak. 


\section{Yosemite National Park Sites}

Three monitoring sites (Dana Meadows, Gin Flat, and Hodgdon Meadow) were set up in Yosemite National Park, on the western slope of the central Sierra Nevada (fig. 1). Yosemite National Park encompasses 3,030 square kilometers $\left(\mathrm{km}^{2}\right)$, with elevation ranging from 657 to 3,997 $\mathrm{m}$ (Lutz and others, 2010). The local vegetation is characteristic of the central Sierra Nevada and consists primarily of subalpine, upper montane, and lower montane coniferous forests; broadleaved upland forests and woodlands; and scrub and chaparral, grassland, meadow, and herb communities (Lutz and others, 2010).

Yosemite National Park is characterized by a Mediterranean climate with hot, dry summers and cool, wet winters. Most of the precipitation in higher elevations falls as snow (Klinger and others, 2006). Mean annual precipitation ranges from 900 millimeters $(\mathrm{mm})$ at lower elevations to $1,200 \mathrm{~mm}$ at higher elevations (Klinger and others, 2006). Average annual snow water equivalent in the snowpack has been estimated to be greater than $700 \mathrm{~mm}$ (Bales and others, 2006). Mean daily summer temperatures range from 33 degrees Celsius $\left({ }^{\circ} \mathrm{C}\right)$ in the lower elevations to $12{ }^{\circ} \mathrm{C}$ in the higher elevations (Klinger and others, 2006). Mean daily winter temperatures range from 8 to $-4{ }^{\circ} \mathrm{C}$ in the lower and higher elevations, respectively (Klinger and others, 2006).

\section{Dana Meadows Site}

The Dana Meadows site (lat 37 $53^{\prime} 45.77^{\prime \prime}$ N., long $119^{\circ} 15^{\prime} 26.95^{\prime \prime}$ W.) is on the eastern edge of Yosemite National Park at 2,965 m NGVD 29 (fig. 1). The vegetation surrounding Dana Meadows is sparse (10-25 percent cover) and dominated by the Sierra lodgepole pine (Pinus contorta var. murrayana) woodlands. Three subwoodland categories make up the Sierra lodgepole pine woodlands: (1) the Sierra lodgepole pine/ mountain pride (Pinus contorta var. murrayana/Penstemon newberryi), (2) the Sierra lodgepole pine (Pinus contorta var. murrayana), and (3) the Sierra lodgepole pine/shorthair sedge (Pinus contorta var. murrayana/Carex exserta; Keeler-Wolf and others, 2012). The geology at this location is predominately granitic with some metasedimentary and metavolcanic rocks (Keeler-Wolf and others, 2012).

\section{Gin Flat Site}

The Gin Flat site (lat $37^{\circ} 46^{\prime} 1.26^{\prime \prime}$ N., long 11946’27.22” W.) is near the western edge of Yosemite National Park at about 2,149 m NGVD 29 (fig. 1). The sparse vegetation (10-25 percent cover) surrounding Gin Flat is Jeffrey pine (Pinus jeffreyi) and whitethorn ceanothus (Ceanothus cordulatus; Keeler-Wolf and others, 2012). This type of vegetation is uncommon in Yosemite National Park because whitethorn ceanothus is typically associated with white fir, and white fir doesn't grow in Yosemite National Park (KeelerWolf and others, 2012). The geology at this location is mostly granitic, with scarce volcanic mudflows (Keeler-Wolf and others, 2012). Precipitation in this area is predominantly snow, and the surrounding area can have the highest amounts of precipitation in Yosemite National Park (Keeler-Wolf and others, 2012).

\section{Hodgdon Meadow Site}

The Hodgdon Meadow site (lat $37^{\circ} 47^{\prime} 46.88^{\prime \prime}$ N., long $119^{\circ} 51^{\prime} 30.81$ ” W.) is about $8 \mathrm{~km}$ northwest of the Gin Flat site, at an elevation of about 1,372 m NGVD 29 (fig. 1). The vegetation surrounding Hodgdon Meadow varies based on location. To the southeast is a discontinuous (40-60 percent cover) intermittently to seasonally flooded grassland meadow, surrounded by a continuous (greater than 60 percent cover) shrub willow (Salix spp.) meadow. The west is dominated by upland graminoids (Keeler-Wolf and others, 2012). To the north of Hodgdon Meadow, sparse (10-25 percent cover) forests dominate: Douglas-fir/ponderosa pine/incense cedar (Pseudotsuga menziesii/Pinus ponderosa/Calocedrus decurrens) forest (Keeler-Wolf and others, 2012). The geology at this location is predominantly granitic (Keeler-Wolf and others, 2012). The area surrounding the site has some of the highest precipitation amounts among locations within Yosemite National Park; however, more of the precipitation falls as rain because of its lower elevation compared to the Gin Flat area (Keeler-Wolf and others, 2012).

\section{Pepperwood Preserve Sites}

Two monitoring sites were set up at the Pepperwood Preserve, a 12.6- $\mathrm{km}^{2}$ nature preserve in Sonoma County, about $20 \mathrm{~km}$ north-northeast of the city of Santa Rosa (fig. 2). The Pepperwood Preserve was established in 1979 to protect native coastal grassland and oak woodland habitats (de Nevers, 2013). The climate surrounding the Pepperwood Preserve is classified as Mediterranean with cool, moist winters and warm, dry summers (de Nevers, 2013). The presence of fog throughout the year reduces temperatures and increases humidity along the coast. The two Pepperwood Preserve sites are approximately $150 \mathrm{~m}$ apart with an elevation difference of $20 \mathrm{~m}$.

\section{Pepperwood Preserve Grass Site}

The Pepperwood Preserve Grass site (lat 38 $34^{\prime} 14.40^{\prime \prime}$ N., long $122^{\circ} 41^{\prime} 38.40^{\prime \prime} \mathrm{W}$.) is at $370 \mathrm{~m} \mathrm{NGVD} 29$ (figs. 2, $3)$. The main vegetation type surrounding this area is Harding grass (Phalaris aquatica) and a large quantity of slender wildoat (Avena barbata). The Harding grass, a perennial, nonnative species, was planted after a 1964 fire to prevent erosion (de Nevers, 2013). The geology at this location is predominantly claystone mélange and serpentine (McLaughlin and others, 2004); organic soil overlays clay soils, which start at a depth of $38 \mathrm{~cm}$, and serpentine rock starts at a depth of $60 \mathrm{~cm}$. 


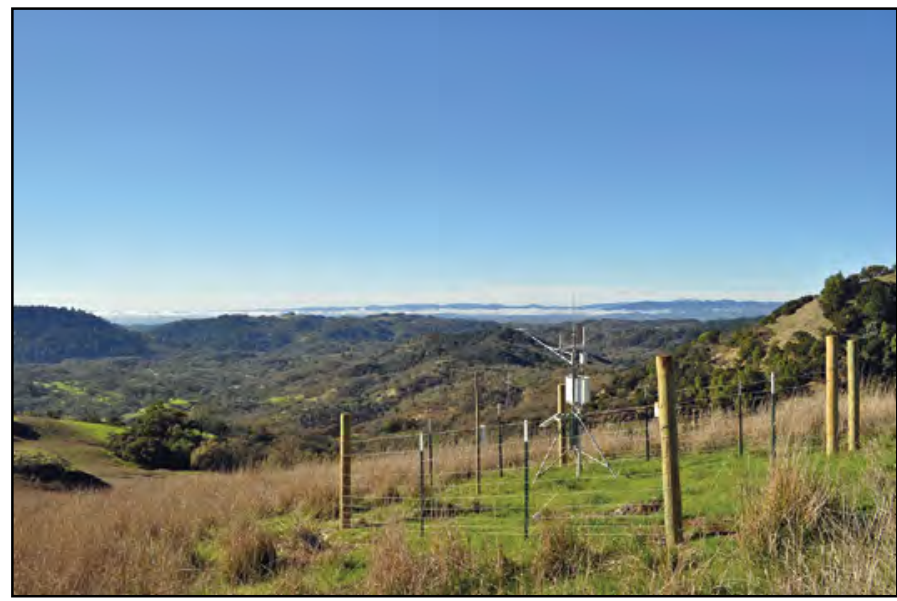

Figure 3. Pepperwood Preserve Grass site (photograph by Frank Anderson, U.S. Geological Survey).

\section{Pepperwood Preserve Oak Site}

The Pepperwood Preserve Oak site (lat 38०34'13.95', N., long $122^{\circ} 41^{\prime} 31.74^{\prime \prime}$ W.) is at $390 \mathrm{~m} \mathrm{NGVD} 29$ and is approximately $150 \mathrm{~m}$ east of the Pepperwood Preserve Grass site (figs. 2, 4). The main vegetation types include the following: Douglas-fir (Pseudotsuga menziesii), California laurel (Umbellularia californica), coast live oak (Quercus agrifolia), scrub oak (Quercus berberidifolia), and sticky monkeyflower (Mimulus viscidus; de Nevers, 2013). Geology at this location is predominantly claystone mélange and serpentine (McLaughlin and others, 2004).

\section{Methods}

Soil moisture and temperature instrumentation were installed at the five monitoring sites at specific depths according to observed changes in the soil profile. For example, the 5-cm-deep HDPs and TDR probes at the Pepperwood Preserve Oak site were installed where the soil profile changed from the surface organic layer to the A1 horizon. The HDPs, TDR probes, and $\mathrm{ECH}_{2} \mathrm{O}$ EC-TM probes were installed in the field according to the standard installation procedures found in the instrument manuals (Campbell Scientific Inc., 1996, 2009, 2016a; Decagon Devices, Inc., 2008). A more detailed description of the HDP and TDR installation process can be found in Flint and others (2008).

Soil samples were collected at each Pepperwood Preserve site at time of instrumentation installation or at a later date from adjacent pits for the determination of bulk density and to describe the soil characteristics. For example, at the Pepperwood Preserve Grass site, the initial soil pit was dug on October 4, 2010. In the winter and summer of water year 2013, soil samples were collected at independent pits within

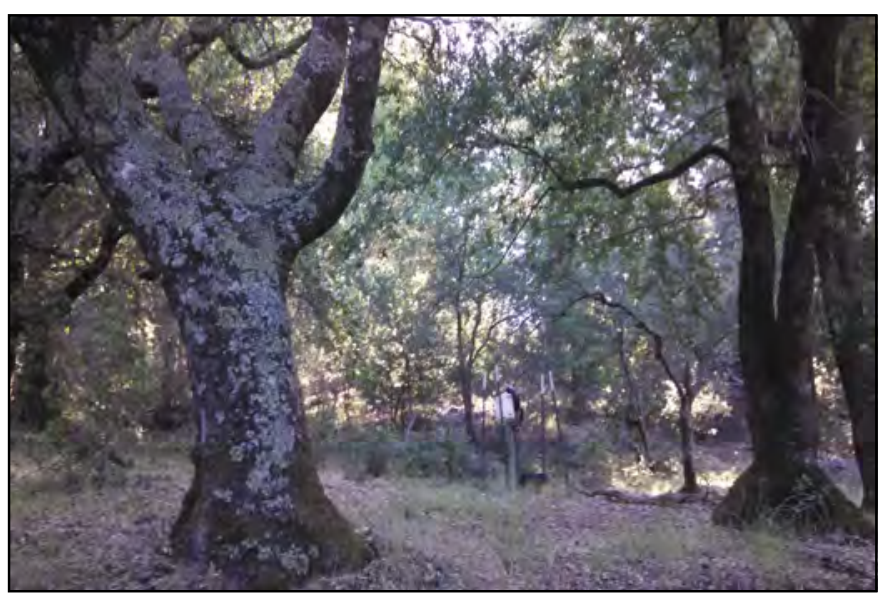

Figure 4. Pepperwood Preserve Oak site (photograph by Frank Anderson, U.S. Geological Survey).

close proximity of the initial pit, as not to disturb the existing instrumentation. At the independent pits, soils were sampled at depths that matched the probe installation depths over a range of soil moisture conditions.

Precipitation data were collected and used as a reference for soil moisture data at the Pepperwood Preserve Grass site; however, rain gages were not installed at the Yosemite National Park sites, so nearby weather stations from other sources were used (California Data Exchange Center, CDEC, http://cdec.water.ca.gov; National Trends Network, NTN, http://nadp.sws.uiuc.edu/ntn/). For the Dana Meadows site, the nearby CDEC weather stations at Ellery Lake (ERY) and Tuolumne Meadows (TUM) provided precipitation data (fig. 1). The CDEC weather station at Gin Flat (GIN; fig. 1) provided precipitation for the Gin Flat site. For the Hodgdon Meadow site, precipitation data were obtained from the Yosemite National Park-Hodgdon Meadow (HDG) NTN station (fig. 1).

\section{Instrumentation}

The HDPs, TDR probes, and $\mathrm{ECH}_{2} \mathrm{O}$ EC-TM probes were used to collect soil moisture and temperature data. Data loggers and telemetric equipment were used for the collection, storage, and transfer of data. A tipping bucket was installed to collect precipitation data for the Pepperwood Preserve sites. The Yosemite National Park sites require a visit to each site to download data from the data loggers, whereas Pepperwood Preserve sites have telemetric equipment to download data remotely.

At the Dana Meadows site, soil moisture and temperature probes (heat dissipation probes [HDPs] and time domain reflectometry [TDR] probes) were placed at depths of 10, 36, 53, and 79 (table 1). The logging instrumentation installed at the Dana Meadows site is found in table 2. 
Table 1. Soil instrumentation at the Dana Meadows site with soil depths, serial numbers, and deployment duration of the instrumentation.

[cm, centimeter; CS, Campbell Scientific; HDP, heat dissipation probe; $\mathrm{mm} /$ dd/yyyy, month/day/year; TDR, time domain reflectometry]

\begin{tabular}{clll}
\hline $\begin{array}{c}\text { Soil depth } \\
\text { (cm) }\end{array}$ & Instrumentation & $\begin{array}{c}\text { HDP serial } \\
\text { number }\end{array}$ & $\begin{array}{c}\text { Duration } \\
\text { (mm/dd/yyyy) }\end{array}$ \\
\hline 10 & CS616 (TDR) & Not available & $09 / 11 / 2005-07 / 26 / 2017$ \\
& CS229(HDP) & 8856 & \\
36 & CS616 (TDR) & Not available & $09 / 11 / 2005-07 / 26 / 2017$ \\
& CS229(HDP) & 8857 & \\
53 & CS616 (TDR) & Not available & $09 / 11 / 2005-07 / 26 / 2017$ \\
& CS229(HDP) & 8860 & \\
79 & CS616 (TDR) & Not available & $09 / 11 / 2005-07 / 26 / 2017$ \\
& CS229(HDP) & 8858 & \\
\hline
\end{tabular}

Table 2. Logging instrumentation at the Dana Meadows site, serial number, and deployment duration of the instrumentation.

[mm/dd/yyyy, month/day/year]

\begin{tabular}{ccc}
\hline $\begin{array}{c}\text { Logging } \\
\text { instrumentation }\end{array}$ & $\begin{array}{c}\text { Serial } \\
\text { number }\end{array}$ & $\begin{array}{c}\text { Duration } \\
\text { (mm/dd/yyy) }\end{array}$ \\
\hline $\begin{array}{c}\text { Campbell Scientific } \\
\text { CR23X data logger }\end{array}$ & Not available & $09 / 11 / 2005-09 / 22 / 2011$ \\
Campbell Scientific & 42228 & $09 / 22 / 2011-07 / 26 / 2017$ \\
CR1000 data logger & & \\
\hline
\end{tabular}

At the Gin Flat site, HDPs and TDR probes were installed at depths of 10, 36, and $72 \mathrm{~cm}$ (table 3 ). The logging instrumentation installed at the Gin Flat site is found in table 4.

At the Hodgdon Meadow site, HDPs were installed at depths of 10, 25, 50, and $80 \mathrm{~cm}$ (table 5). The TDR probes were installed at depths of 10 and $50 \mathrm{~cm}$. The $\mathrm{ECH}_{2} \mathrm{O}$ EC-TM soil moisture probes were installed at depths of 25 and $80 \mathrm{~cm}$ (table 5). The logging instrumentation installed at the Hodgdon Meadow site is described in table 6.

At the Pepperwood Preserve Grass site, HDPs and TDR probes were placed at depths of $15,30,60$, and $90 \mathrm{~cm}$ (table 7). The logging, telemetered, and solar-powered instrumentation installed at the Pepperwood Preserve Grass site is found in table 8 .

At the Pepperwood Preserve Oak site, HDPs and TDR probes were placed at depths of 5, 20, 45, and $70 \mathrm{~cm}$ (table 9). The logging, telemetered, and solar-powered instrumentation installed at the Pepperwood Preserve Oak site is found in table 10.

Table 3. Soil instrumentation at the Gin Flat site with soil depths, serial numbers, soil observations, and deployment duration of the instrumentation.

[CS, Campbell Scientific; HDP, heat dissipation probe; mm/dd/yyyy, month/day/year; TDR, time domain reflectometry]

\begin{tabular}{clllr}
\hline $\begin{array}{c}\text { Soil depth } \\
\text { (cm) }\end{array}$ & Instrumentation & \multicolumn{1}{c}{ Serial number } & \multicolumn{1}{c}{ Soil observations } & \multicolumn{1}{c}{$\begin{array}{c}\text { Duration } \\
\text { (mm/dd/yyyy) }\end{array}$} \\
\hline 10 & CS615 (TDR) & Not available & Loamy sand & $09 / 01 / 2005-07 / 26 / 2017$ \\
& CS229 (HDP) & 8567 & & $09 / 01 / 2005-07 / 26 / 2017$ \\
36 & CS616 (TDR) & Not available & Loamy sand & \\
& CS229 (HDP) & 8566 & & $09 / 01 / 2005-07 / 26 / 2017$ \\
& CS616 (TDR) & Not available & Loamy sand, some fractured granitic bedrock & \\
& CS229 (HDP) & 7677 & & \\
\hline
\end{tabular}

Table 4. Logging instrumentation at the Gin Flat site, serial number, and deployment duration of the instrumentation.

$[\mathrm{mm} / \mathrm{dd} / \mathrm{yyyy}, \mathrm{month} / \mathrm{day} /$ year $]$

\begin{tabular}{ccc}
\hline $\begin{array}{c}\text { Logging } \\
\text { instrumentation }\end{array}$ & $\begin{array}{c}\text { Serial } \\
\text { number }\end{array}$ & $\begin{array}{c}\text { Duration } \\
\text { (mm/dd/yyy) }\end{array}$ \\
\hline $\begin{array}{c}\text { Campbell Scientific } \\
\text { CR23X data logger }\end{array}$ & Not available & $09 / 01 / 2005-09 / 22 / 2011$ \\
Campbell Scientific & 27795 & $09 / 22 / 2011-07 / 26 / 2017$ \\
CR1000 data logger & & \\
\hline
\end{tabular}


Table 5. Soil instrumentation at the Hodgdon Meadow site with soil depths, serial numbers, soil observations, and deployment duration of the instrumentation.

[cm, centimeter; CS, Campbell Scientific; EC-TM, $\mathrm{ECH}_{2} \mathrm{O}$ EC-TM soil moisture probe; HDP, heat dissipation probe; mm/dd/yyyy, month/day/year; TDR, time domain reflectometry]

\begin{tabular}{cclll}
\hline $\begin{array}{c}\text { Soil depth } \\
\text { (cm) }\end{array}$ & Instrumentation & \multicolumn{1}{c}{ Serial number } & \multicolumn{1}{c}{ Soil observations } & Duration \\
\hline 10 & CS616 (TDR) & Not available & Slightly decomposed plant material, & $10 / 08 / 2010-07 / 25 / 2017$ \\
& grass roots present & Sandy to coarse sandy loam, some grass \\
25 & EC-TM & Not available & $10 / 08 / 2010-07 / 25 / 2017$ \\
& CS229 (HDP) & 9375 & roots & $10 / 08 / 2010-11 / 12 / 2014$ \\
50 & CS616 (TDR) & Not available & Sandy loam & \\
& CS229 (HDP) & 9376 & Sandy loam, ponded water & $10 / 08 / 2010-11 / 06 / 2013$ \\
80 & EC-TM & Not available & & $10 / 08 / 2010-07 / 25 / 2017$ \\
\hline
\end{tabular}

Table 6. Logging and instrumentation at the Hodgdon Meadow site, serial number, and deployment duration of the instrumentation.

$[\mathrm{mm} / \mathrm{dd} / \mathrm{yyyy}, \mathrm{month} / \mathrm{day} / \mathrm{year}]$

\begin{tabular}{llc}
\hline Logging instrumentation & $\begin{array}{c}\text { Serial } \\
\text { number }\end{array}$ & $\begin{array}{c}\text { Duration } \\
\text { (mm/dd/yyy) }\end{array}$ \\
\hline $\begin{array}{c}\text { Campbell Scientific } \\
\text { CR23X data logger }\end{array}$ & Not available & $10 / 08 / 2010-07 / 25 / 2017$ \\
Campbell Scientific & 27798 & $01 / 03 / 2012-07 / 25 / 2017$ \\
CR1000 data logger & & \\
\hline
\end{tabular}

Table 7. Soil instrumentation at the Pepperwood Preserve Grass site with soil depths, serial numbers, soil observations, bulk density, and deployment duration of the instrumentation.

[cm, centimeter; CS, Campbell Scientific; HDP, heat dissipation probe; mm/dd/yyyy, month/day/year; TDR, time domain reflectometry]

\begin{tabular}{|c|c|c|c|c|c|}
\hline $\begin{array}{c}\text { Soil depth } \\
\text { (cm) }\end{array}$ & Instrumentation & $\begin{array}{c}\text { Serial } \\
\text { number }\end{array}$ & Soil observations & $\begin{array}{c}\text { Bulk } \\
\text { density }\end{array}$ & $\begin{array}{c}\text { Duration } \\
\text { (mm/dd/yyyy) }\end{array}$ \\
\hline 15 & $\begin{array}{l}\text { CS616 (TDR) } \\
\text { CS229 (HDP) }\end{array}$ & $\begin{array}{l}\text { Not available } \\
9378\end{array}$ & Between organic layer and A1 horizon & 1.15 & $10 / 04 / 2010-08 / 17 / 2017$ \\
\hline 30 & $\begin{array}{l}\text { CS616 (TDR) } \\
\text { CS229 (HDP) }\end{array}$ & $\begin{array}{l}\text { Not available } \\
9379\end{array}$ & Between A1 and B horizons: silty clay loam & 1.35 & $10 / 04 / 2010-08 / 17 / 2017$ \\
\hline 60 & $\begin{array}{l}\text { CS616 (TDR) } \\
\text { CS229 (HDP) }\end{array}$ & $\begin{array}{l}\text { Not available } \\
9380\end{array}$ & Weathered serpentine rock and clay & 1.28 & $10 / 04 / 2010-08 / 17 / 2017$ \\
\hline 90 & $\begin{array}{l}\text { CS616 (TDR) } \\
\text { CS229 (HDP) }\end{array}$ & $\begin{array}{l}\text { Not available } \\
9381\end{array}$ & Weathered solid serpentine rock & 1.68 & $10 / 04 / 2010-08 / 17 / 2017$ \\
\hline
\end{tabular}


Table 8. Logging and telemetry instrumentation and solar-power system at the Pepperwood Preserve Grass site and deployment duration of the instrumentation.

[MHz, megahertz; mm/dd/yyyy, month/day/year]

\begin{tabular}{|c|c|}
\hline $\begin{array}{l}\text { Logging and telemetry } \\
\text { instrumentation }\end{array}$ & $\begin{array}{c}\text { Duration } \\
\text { (mm/dd/yyyy) }\end{array}$ \\
\hline Campbell Scientific CR3000 micrologger & $10 / 04 / 2010-08 / 17 / 2017$ \\
\hline $\begin{array}{l}\text { Campbell Scientific CE8 eight-channel } \\
\text { current-excitation module }\end{array}$ & $10 / 04 / 2010-08 / 17 / 2017$ \\
\hline $\begin{array}{l}\text { RAVENXTV: AirLink CDMA Cellular } \\
\text { Digital Modem for Verizon Systems }\end{array}$ & $10 / 04 / 2010-08 / 17 / 2017$ \\
\hline $\begin{array}{l}\text { Campbell Scientific RF401 900-MHz } \\
\text { spread-spectrum radio }\end{array}$ & $10 / 04 / 2010-08 / 17 / 2017$ \\
\hline Solar-power system & Duration \\
\hline $\begin{array}{l}\text { Campbell Scientific SP10 } 10 \text { watt solar } \\
\text { panel }\end{array}$ & $10 / 04 / 2010-08 / 17 / 2017$ \\
\hline $\begin{array}{l}\text { Campbell Scientific PS100 rechargeable } \\
\text { power supply }\end{array}$ & $10 / 04 / 2010-08 / 17 / 2017$ \\
\hline
\end{tabular}

Table 9. Soil instrumentation at the Pepperwood Preserve Oak site with soil depths, serial number, soil observations, bulk density, and duration of instrumentation.

[cm, centimeter; CS, Campbell Scientific; HDP, heat dissipation probe; mm/dd/yyyy, month/day/year; TDR, time domain reflectometry]

\begin{tabular}{|c|c|c|c|c|c|}
\hline $\begin{array}{l}\text { Soil depths } \\
\text { (cm) }\end{array}$ & Instrumentation & $\begin{array}{l}\text { HDP serial } \\
\text { number }\end{array}$ & Soil observations & $\begin{array}{c}\text { Bulk } \\
\text { density }\end{array}$ & $\begin{array}{c}\text { Duration } \\
\text { (mm/dd/yyyy) }\end{array}$ \\
\hline 5 & $\begin{array}{l}\text { CS616 (TDR) } \\
\text { CS229 (HDP) }\end{array}$ & $\begin{array}{l}\text { Not available } \\
10065\end{array}$ & Between organic layer and A1 horizon & 0.85 & $07 / 19 / 2011-08 / 17 / 2017$ \\
\hline 20 & $\begin{array}{l}\text { CS616 (TDR) } \\
\text { CS229 (HDP) }\end{array}$ & $\begin{array}{l}\text { Not available } \\
10066\end{array}$ & Between A1 and B horizons: silty clay loam & 0.92 & $07 / 19 / 2011-08 / 17 / 2017$ \\
\hline 45 & $\begin{array}{l}\text { CS616 (TDR) } \\
\text { CS229 (HDP) }\end{array}$ & $\begin{array}{l}\text { Not available } \\
10067\end{array}$ & Alluviated zone with some decomposed serpentine rock & 0.98 & $07 / 19 / 2011-08 / 17 / 2017$ \\
\hline 70 & $\begin{array}{l}\text { CS616 (TDR) } \\
\text { CS229 (HDP) }\end{array}$ & $\begin{array}{l}\text { Not available } \\
10068\end{array}$ & Weathered solid serpentine rock & 1.42 & $07 / 19 / 2011-08 / 17 / 2017$ \\
\hline
\end{tabular}

Table 10. Logging and telemetry instrumentation and solar-power system at the Pepperwood Preserve Oak site and duration of instrumentation.

[MHz, megahertz; mm/dd/yyyy, month/day/year]

\begin{tabular}{cc}
\hline $\begin{array}{c}\text { Logging and telemetry } \\
\text { instrumentation }\end{array}$ & $\begin{array}{c}\text { Duration } \\
\text { (mm/dd/yyy) }\end{array}$ \\
\hline Campbell Scientific CR3000 micrologger & $07 / 19 / 2011-08 / 15 / 2012$ \\
Campbell Scientific CR1000 micrologger & $08 / 15 / 2012-08 / 17 / 2017$ \\
$\begin{array}{c}\text { Campbell Scientific CFM100 compact } \\
\text { flash module }\end{array}$ & $08 / 15 / 2012-08 / 17 / 2017$ \\
$\begin{array}{c}\text { Campbell Scientific CE8 eight-channel } \\
\text { current-excitation module }\end{array}$ & $10 / 04 / 2010-08 / 17 / 2017$ \\
$\begin{array}{c}\text { Campbell Scientific RF401 900-MHz } \\
\text { spread-spectrum radio }\end{array}$ & $01 / 01 / 2013-08 / 17 / 2017$ \\
\end{tabular}

\begin{tabular}{cc}
\hline $\begin{array}{c}\text { Logging and telemetry } \\
\text { instrumentation }\end{array}$ & $\begin{array}{c}\text { Duration } \\
\text { (mm/dd/yyyy) }\end{array}$ \\
\hline Solar-power system & Duration \\
\hline 20-watt solar panel & $01 / 01 / 2013-08 / 17 / 2017$ \\
SunSaver 6 photovoltaic system & $01 / 01 / 2013-08 / 17 / 2017$ \\
controllers & \\
100-amp-hour deep cycle battery & $01 / 01 / 2013-08 / 17 / 2017$ \\
\hline
\end{tabular}




\section{Heat Dissipation Probes}

\section{Description}

Campbell Scientific model 229 HDPs were deployed at each of the five soil moisture monitoring sites to determine water potential at specific soil depths (Campbell Scientific Inc., 2009). Heat dissipation (also called thermal diffusivity) is an indirect method of measuring soil water matric potential. A heating element is encased in a ceramic body with a thermocouple at midlength. When the HDP is installed, water potential changes in the surrounding soils result in a water flux with the ceramic matrix. The heating element initiates a heat pulse, and the temperature increase in the surrounding ceramic/water complex after 20 seconds (delta $T$ ) is measured by the thermocouple. The delta $T$ is dependent on the thermal properties of the ceramic (including water content) and can thus be calibrated and used to compute soil water matric potential. The heat transfer property between the heating element and the instrument's ceramic casing varies enough to require calibration of each sensor individually (Flint and others, 2002). Accuracy of the HDP matric-potential measurement depends on the porous ceramic material, but with individual sensor calibration, measurements can be made with an accuracy of \pm 0.1 bar or better (Flint and others, 2002; McMahon and others, 2003).

\section{Calibration}

The HDPs were calibrated before field deployment using the procedure described in Flint and others (2002). The following equation was used for calibration of the HDPs:

$$
\psi=\frac{\psi_{0}\left(\mathrm{~T}^{*-\frac{1}{m}}-1\right)^{\frac{1}{n}}}{\alpha}
$$

where

$$
\begin{array}{ll}
\Psi \quad \text { is the soil water matric potential } \\
\text { (megapascals); }
\end{array}
$$$$
n, m \text {, and } \alpha \quad \text { are fitting parameters. }
$$

Calibration parameters were fit to a van Genuchten curve (van Genuchten, 1980) that allowed the calibration to extend to wet and very dry soil conditions. Water potential was calculated by using a subroutine in the Campbell Scientific data logger or calculated during postprocessing by using a Microsoft Excel macros routine. All of the Yosemite National Park sites used the data logger subroutine, except for the Hodgdon Meadow site, which used the Excel macros routine.
At the Pepperwood Preserve sites from October 4, 2010, to January 17,2013 , water potential was calculated by using the Excel macros routine. After January 17, 2013, calculations were performed using the data logger subroutine. In all cases, final water potential values for all sites were calculated using parameters obtained during initial calibrations using equation 1 .

\section{Time Domain Reflectometry}

\section{Description}

Campbell Scientific TDR probe models 615 and 616 were used at each of the five sites to determine volumetric water content (VWC) at specific soil depths (Campbell Scientific, 1996, 2016a). The TDR probes use an indirect method to measure soil water content. They contain stainless steel rods that are sensitive to the dielectric permittivity of the surrounding material. The TDR output wave is converted to VWC using a calibration equation and laboratory VWC measurements. The model CS615 TDR probe is accurate to \pm 2 percent VWC, and the model CS616 TDR probe is accurate to \pm 2.5 percent VWC.

\section{Calibration}

At the Yosemite National Park sites, VWC was determined using the Campbell Scientific calibration factors derived in their soils laboratory (Campbell Scientific, 2016a). The coefficients are accurate for mineral soils with bulk density less than 1.55 grams per cubic centimeter $\left(\mathrm{g} / \mathrm{cm}^{3}\right)$ and clay content less than 30 percent. Soil characteristics at the Yosemite National Park sites are generally loamy sand and fall within the suitability of the Campbell Scientific calibration factors. The $\operatorname{VWC} \theta_{v}(\tau)$ was determined using the following quadratic equation:

$$
\theta_{v}(\tau)=C_{0}+C_{1} \times \tau+C_{2} \tau^{2}
$$

where

$\tau \quad$ is the probe's wave period (microseconds) and $C_{0}, C_{1}$, and $C_{2}$ are the laboratory derived calibration factors.

The calibrations for the CS616 TDR probes were completed using the following equation:

$$
\theta_{v}(\tau)=-0.0663-0.0063 \tau+0.0007 \times \tau^{2}
$$

The calibrations for the CS615 TDR probes were completed using the following equation:

$$
\theta_{v}(\tau)=-0.187-0.037 \tau+0.335 \times \tau^{2}
$$


At the Pepperwood Preserve sites, soil cores with a volume of 60 cubic centimeters $\left(\mathrm{cm}^{3}\right)$ were sampled at each depth that corresponded to the positioning of the instrumentation in the field to determine gravimetric water content, bulk density, and VWC. Two end member samples were collected: one sample when field conditions were dry (late summer) and a second sample when soils were saturated (winter). Gravimetric water content was calculated using the following equation:

$$
\theta_{g}=\frac{m_{w e t}-m_{d r y}}{m_{d r y}}
$$

where

$$
\begin{aligned}
& \theta_{g} \quad \begin{array}{l}
\text { is the gravimetric water content, a } \\
\text { dimensionless fraction; }
\end{array} \\
& m_{w e t} \quad \begin{array}{l}
\text { is the mass of the saturated wet soil; and } \\
m_{d r y} \quad \text { is the mass of the dry soil at } 105^{\circ} \mathrm{C} \text {, in grams. }
\end{array}
\end{aligned}
$$

Bulk density was calculated using the following equation:

$$
\rho_{\text {bulk }=\frac{m_{d r y}}{\text { volume }_{\text {cylinder }}}}
$$

where

$$
\begin{gathered}
\rho_{\text {bulk }} \quad \begin{array}{l}
\text { is the bulk density, in grams per cubic } \\
\text { centimeter, and }
\end{array} \\
\text { volume }_{\text {cylinder }} \quad \begin{array}{c}
\text { is the volume, in cubic centimeters, of the } \\
\text { core used in sampling. }
\end{array}
\end{gathered}
$$

The VWC $\left(\theta_{v}, m^{3} / m^{3}\right)$ for the end-member samples was calculated by multiplying the gravimetric water content and the bulk density and dividing by the density of water using the following equation:

$$
\theta_{v}=\frac{\theta_{g} \times \rho_{\text {bulk }}}{\rho_{\text {water }}}
$$

where

$$
\begin{gathered}
\rho_{\text {water }} \text { is the density of water, in grams per cubic } \\
\text { centimeter. }
\end{gathered}
$$

Final calibration curves were determined by plotting the wet- and dry-soil VWC values with corresponding signal outputs from the TDRs at the time of core collection. The slopes and intercept used in calculating VWC for the Pepperwood Preserve Grass and Oak sites are in table 11.
Table 11. Site name, depth, slope, and intercept for Pepperwood Preserve Grass and 0 ak sites used in time domain reflectometry probe calibrations.

[cm, centimeter; $\mathrm{cm}^{3}$, cubic centimeter]

\begin{tabular}{lccc}
\hline \multicolumn{1}{c}{ Site } & $\begin{array}{c}\text { Soil depth } \\
\text { (cm) }\end{array}$ & Slope & $\begin{array}{c}\text { Intercept } \\
\left(\mathbf{c m}^{3} / \mathbf{c m}^{3}\right)\end{array}$ \\
\hline Pepperwood Preserve Grass & 15 & 0.27 & -0.08 \\
Pepperwood Preserve Grass & 30 & 0.47 & -0.42 \\
Pepperwood Preserve Grass & 60 & 0.35 & -0.19 \\
Pepperwood Preserve Grass & 90 & 0.14 & 0.12 \\
Pepperwood Preserve Oak & 5 & 0.03 & -0.46 \\
Pepperwood Preserve Oak & 20 & 0.05 & -0.93 \\
Pepperwood Preserve Oak & 45 & 0.06 & -1.29 \\
Pepperwood Preserve Oak & 70 & 0.06 & -1.51 \\
\hline
\end{tabular}

Total soil water content was calculated for all sites using a weighted average based on total soil profile depth. For example, at the Pepperwood Preserve Oak site, the 5-cm-deep probe represents $0-12.7 \mathrm{~cm}$ of the soil profile, the 20 -cm-deep probe represents $12.7-33 \mathrm{~cm}$, the $45-\mathrm{cm}$-deep probe represents $33-55.9 \mathrm{~cm}$, and the 70-cm-deep probe represents $55.9-70 \mathrm{~cm}$. An average was calculated based on the represented depthinterval thickness corresponding to each probe. For example, at the Pepperwood Preserve Oak site, the following calculation was used:

$$
\begin{gathered}
T w=\left(d_{1} \times 12.7\right)+\left(d_{2} \times 20.3\right)+ \\
\left(d_{3} \times 22.9\right)+\left(d_{4} \times 10.16\right)
\end{gathered}
$$

where

$$
\begin{aligned}
& T w \quad \text { is the total soil water content (centimeter); } \\
& d_{1}-d_{4} \quad \text { are water content values at the soil probes } \\
& \text { from shallowest to deepest; and }
\end{aligned}
$$

$12.7,20.3,22.9$, and 10.16 are the respective layer thicknesses (centimeter). 


\section{$\mathrm{ECH}_{2} \mathrm{O}$ EC-TM Soil Moisture Probes}

\section{Description}

At the Hodgdon Meadow site in Yosemite National Park, Decagon $\mathrm{ECH}_{2} \mathrm{O}$ EC-TM probes were used to determine the VWC at specific soil depths (Decagon Devices, Inc., 2008). The $\mathrm{ECH}_{2} \mathrm{O}$ EC-TM probes measure soil water content indirectly through the use of an electromagnetic field to measure the dielectric permittivity of the surrounding material. The probe supplies a 70 megahertz $(\mathrm{MHz})$ oscillating wave to the three probe prongs that are sensitive to the dielectric permittivity of the surrounding material. The stored charge is proportional to soil dielectric and soil VWC. The internal microprocessor measures the stored charge and outputs a value from the probe.

\section{Calibration}

The $\mathrm{ECH}_{2} \mathrm{O}$ EC-TM probes are precalibrated at Decagon Devices, Inc., in multiple media types (mineral, organic, potting soil, and rock wool) to create a general calibration equation that is suitable in most media types with accuracy greater than \pm 3 percent for the VWC and $\pm 1^{\circ} \mathrm{C}$ for temperature (Decagon Devices, Inc., 2008). The calibration equation used is the following:

$$
\theta=1.087 \times 10^{-3} \times R a w-0.629
$$

where

$$
\begin{gathered}
\theta \quad \begin{array}{c}
\text { is volumetric water content (cubic meters per } \\
\text { cubic meters), and }
\end{array} \\
\text { Raw is the output of the probe sensors. }
\end{gathered}
$$

\section{Tipping Bucket}

A Campbell Scientific TE525 Tipping Bucket Rain Gage was installed at the Pepperwood Preserve Grass site per manufacturer instructions to measure precipitation (Campbell Scientific, 2016b). The TE525 rain gage was adapted from the standard National Weather Service tipping bucket rain gage and outputs a switch closure for each bucket tip (Campbell Scientific, 2016b). The rain gage funnels precipitation into a bucket mechanism that tips when filled to a predetermined calibrated level. A magnet attached to the tipping mechanism triggers a switch as the bucket tips. The switch closure is recorded by the pulse-counting circuitry of the data logger. The TE525 is accurate to \pm 1 percent up to 25.4 millimeters per hour $(\mathrm{mm} / \mathrm{hr}) ;+0,-3$ percent from 25.4 to $50.8 \mathrm{~mm} / \mathrm{hr}$; and $+0,-5$ percent from 50.8 to $76.2 \mathrm{~mm} / \mathrm{hr}$.

\section{Data Loggers}

Various data loggers were installed at each of the five sites. The data loggers installed at the Yosemite National Park sites were Campbell Scientific CR23X and Campbell Scientific CR1000. The data loggers installed at the Pepperwood Preserve sites were Campbell Scientific CR3000 and Campbell Scientific CR1000. Campbell Scientific CFM100 compact flash module and CE8 eightchannel current-excitation modules were also installed at the Pepperwood Preserve Grass and Oak sites.

\section{Telemetry}

Campbell Scientific RF401 900-MHz spread spectrum radios were installed at each of the Pepperwood Preserve Grass and Oak sites to allow for remote access and retrieval of site data to a computer station. Spread spectrum radios spread the normally narrowband information signal over a relatively wide band of frequencies, which allows the communications to be more immune to noise and interference from radio frequency sources.

\section{Results}

Graphical representations of the soil water matric potential (in megapascals, MPa), precipitation (in $\mathrm{mm}$ ), VWC (in cubic centimeters of water per cubic centimeter of soil volume, $\mathrm{cm}^{3} / \mathrm{cm}^{3}$ ), soil temperature (in ${ }^{\circ} \mathrm{C}$ ) at all depths, and total soil water content (in $\mathrm{cm}$ ) for the total measured soil column for all five sites are presented in figures 5-24. Data from all five sites in the form of comma separated values (.csv) files are included in tables 12-16. For the Yosemite National Park sites, the USGS manually downloaded data during site visits, typically semiannually and when weather conditions permitted. For the Pepperwood Preserve sites, the USGS used telemetry and transmission equipment to send data to a computer at the USGS California Water Science Center office in Sacramento, California.

Unless otherwise stated, all data, metadata, and related materials are considered to satisfy the quality standards relative to the purpose for which the data were collected. Although these data and associated metadata have been reviewed for accuracy and completeness and approved for release by the USGS, no warranty expressed or implied is made regarding the display or utility of the data on any other system or for general or scientific purposes, nor shall the act of distribution constitute any such warranty. 


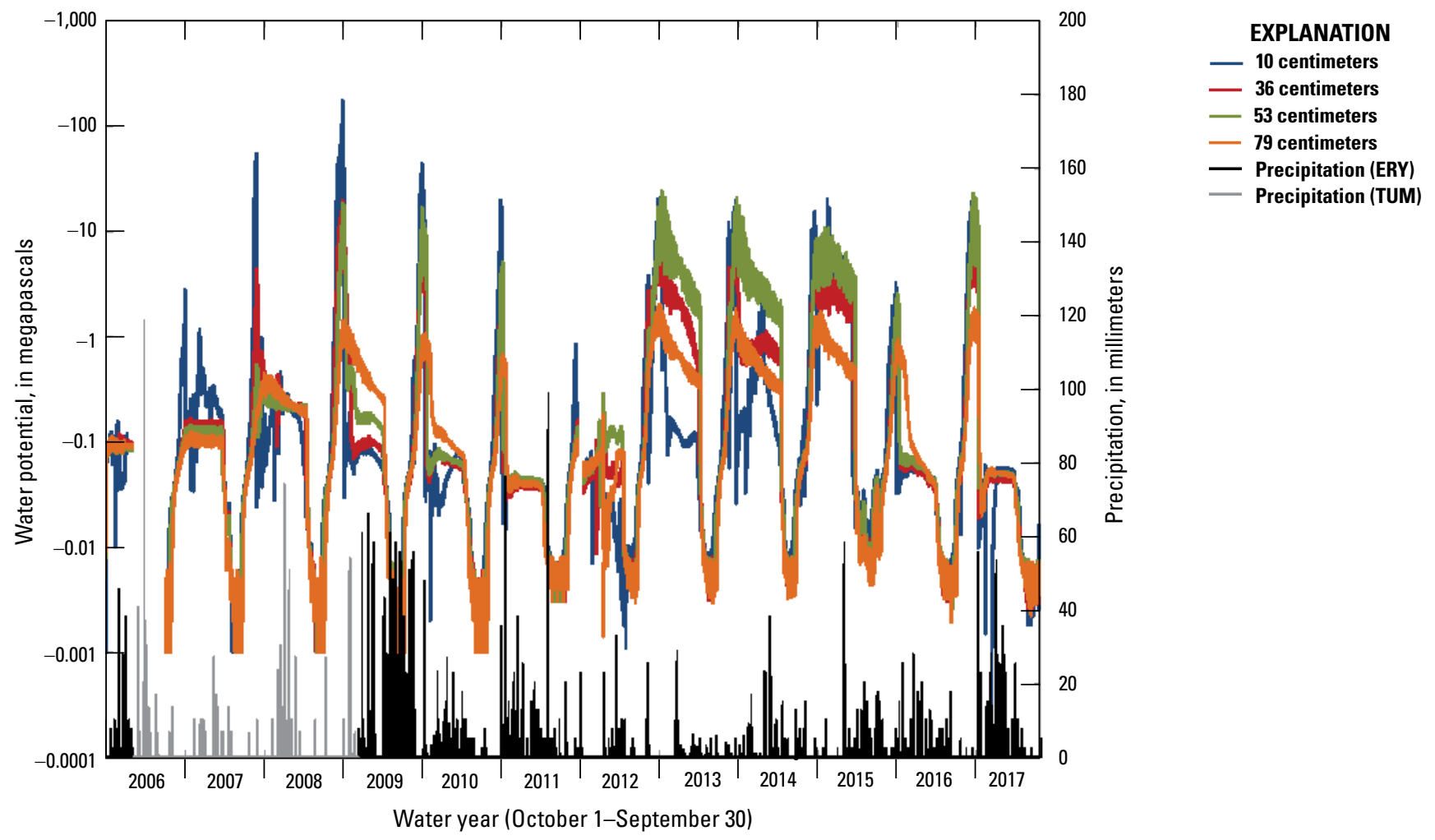

Figure 5. Soil water matric potential for the Dana Meadows site at four depths. Precipitation data from California Data Exchange Center, CDEC, https://cdec.water.ca.gov/, ERY, Ellery Lake; TUM, Tuolumne Meadows.

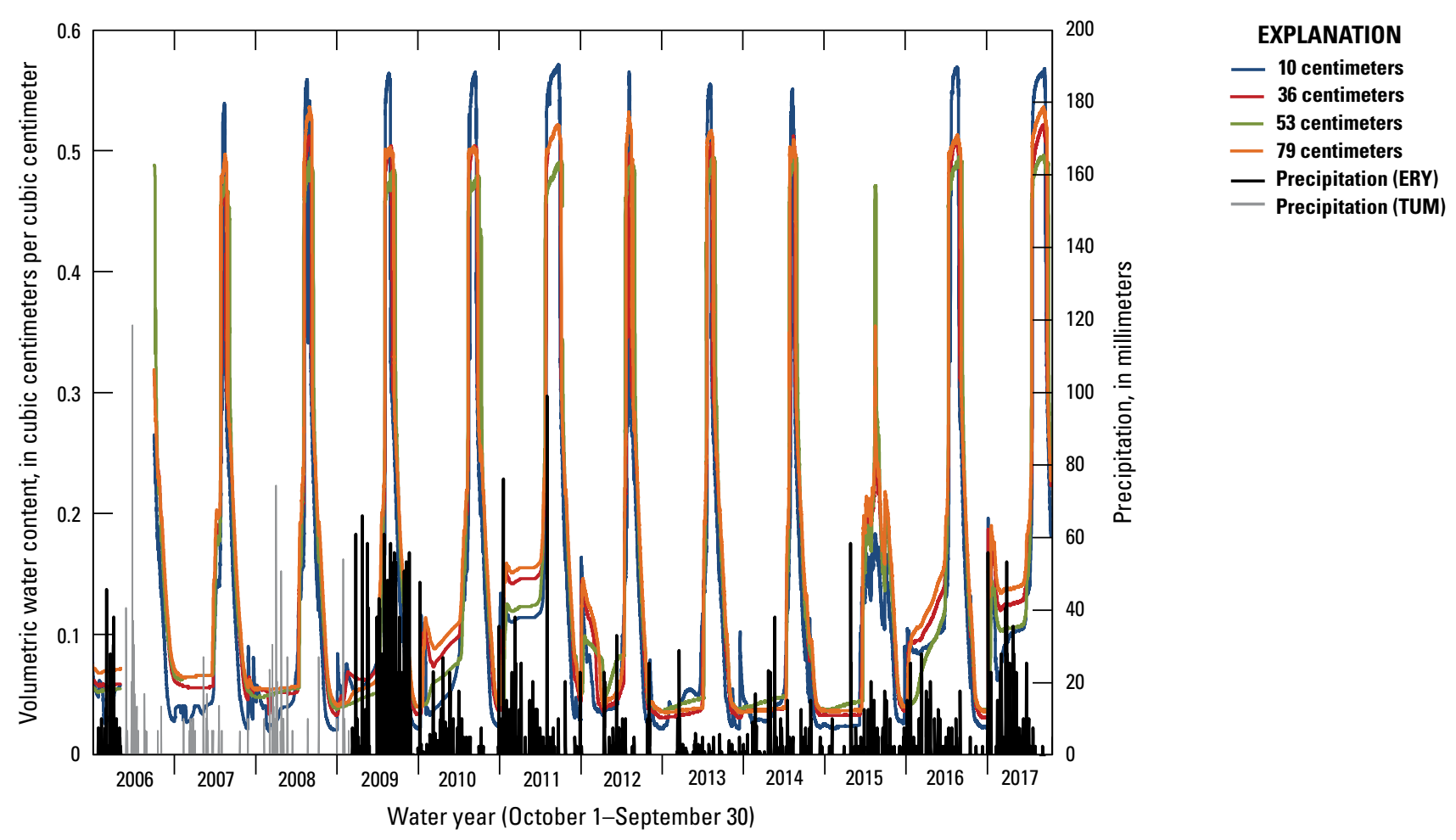

Figure 6. Volumetric soil water content for the Dana Meadows site at four depths. Precipitation data from California Data Exchange Center, CDEC, https://cdec.water.ca.gov/, ERY, Ellery Lake; TUM, Tuolumne Meadows. 


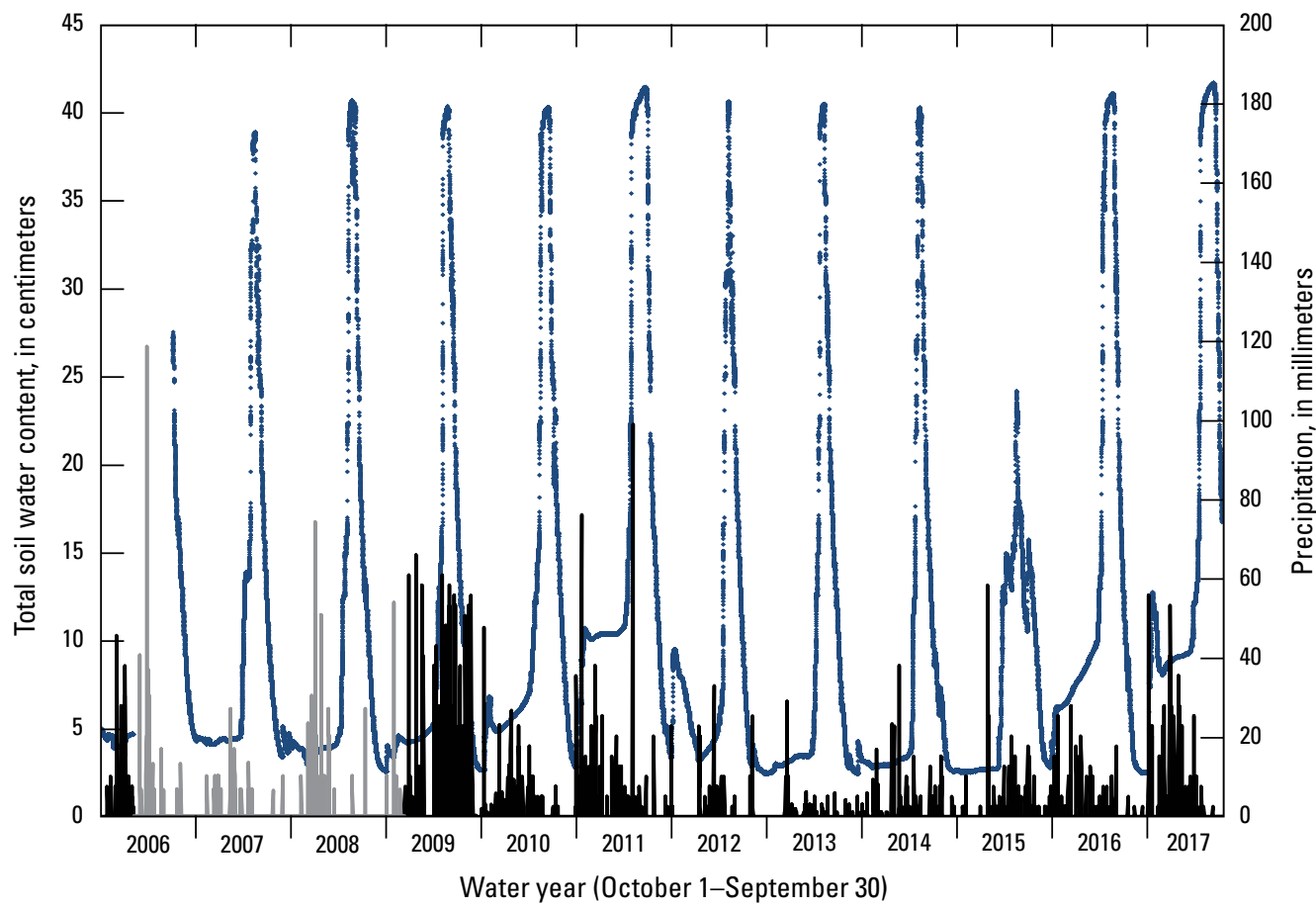

EXPLANATION

Total soil water content

- Precipitation (ERY)

- Precipitation (TUM)

Figure 7. Total soil water content for the Dana Meadows site to the depth of 79 centimeters. Precipitation data from California Data Exchange Center, CDEC, https://cdec.water.ca.gov/, ERY, Ellery Lake; TUM, Tuolumne Meadows.

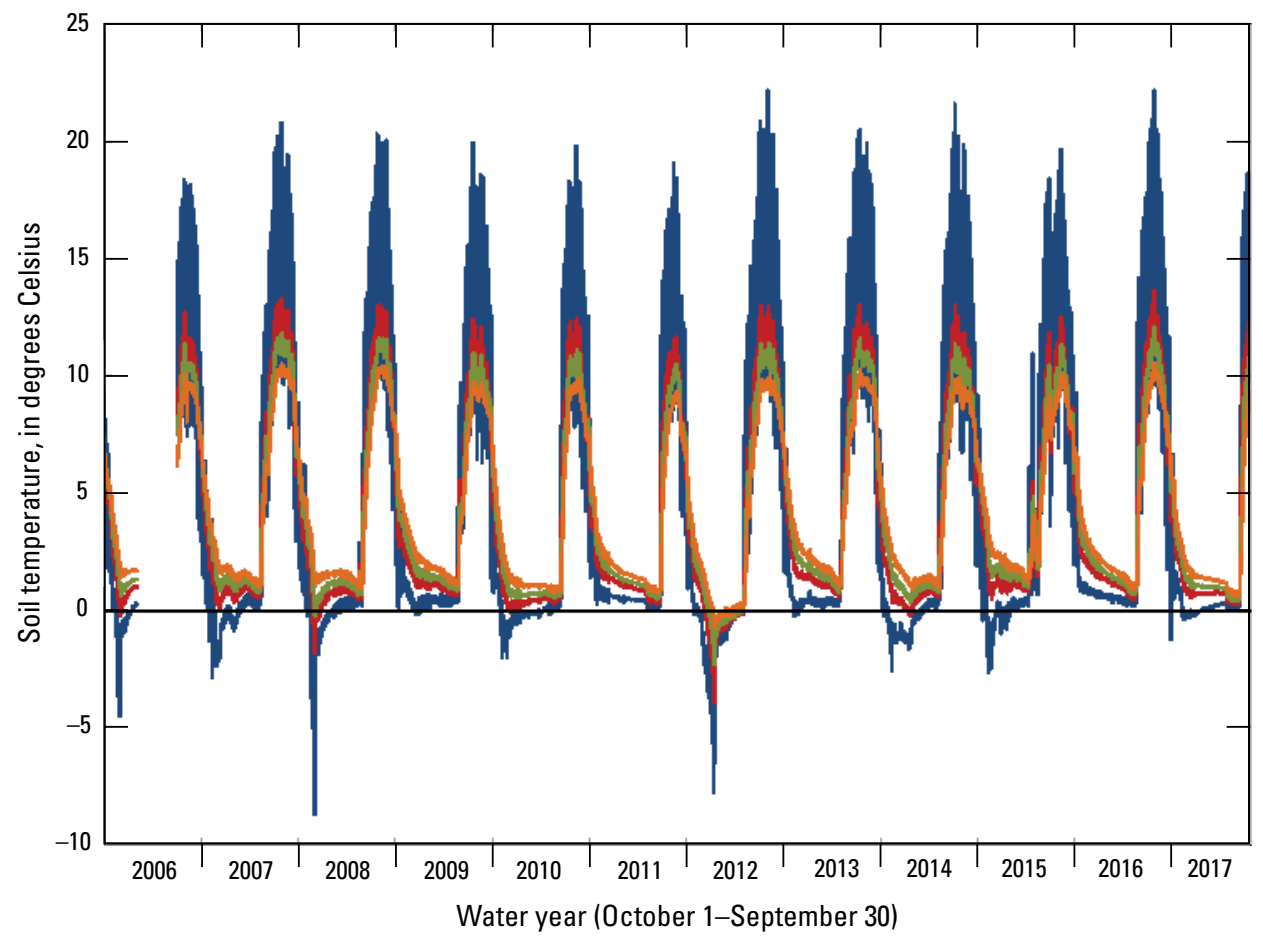

Figure 8. Soil temperature for the Dana Meadows site at four depths. 


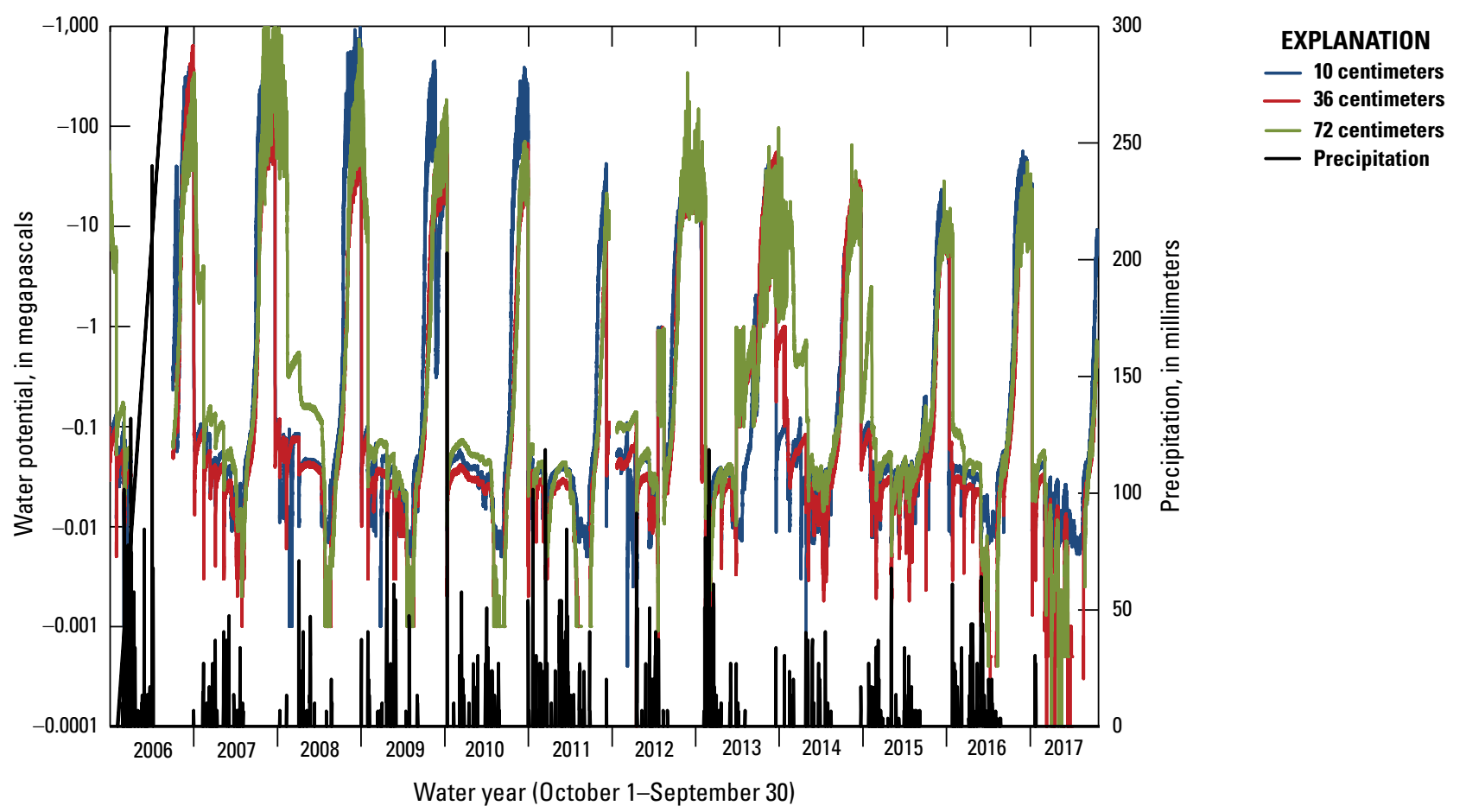

Figure 9. Soil water matric potential for the Gin Flat site at three depths. Precipitation data from California Data Exchange Center, CDEC, https://cdec.water.ca.gov/.

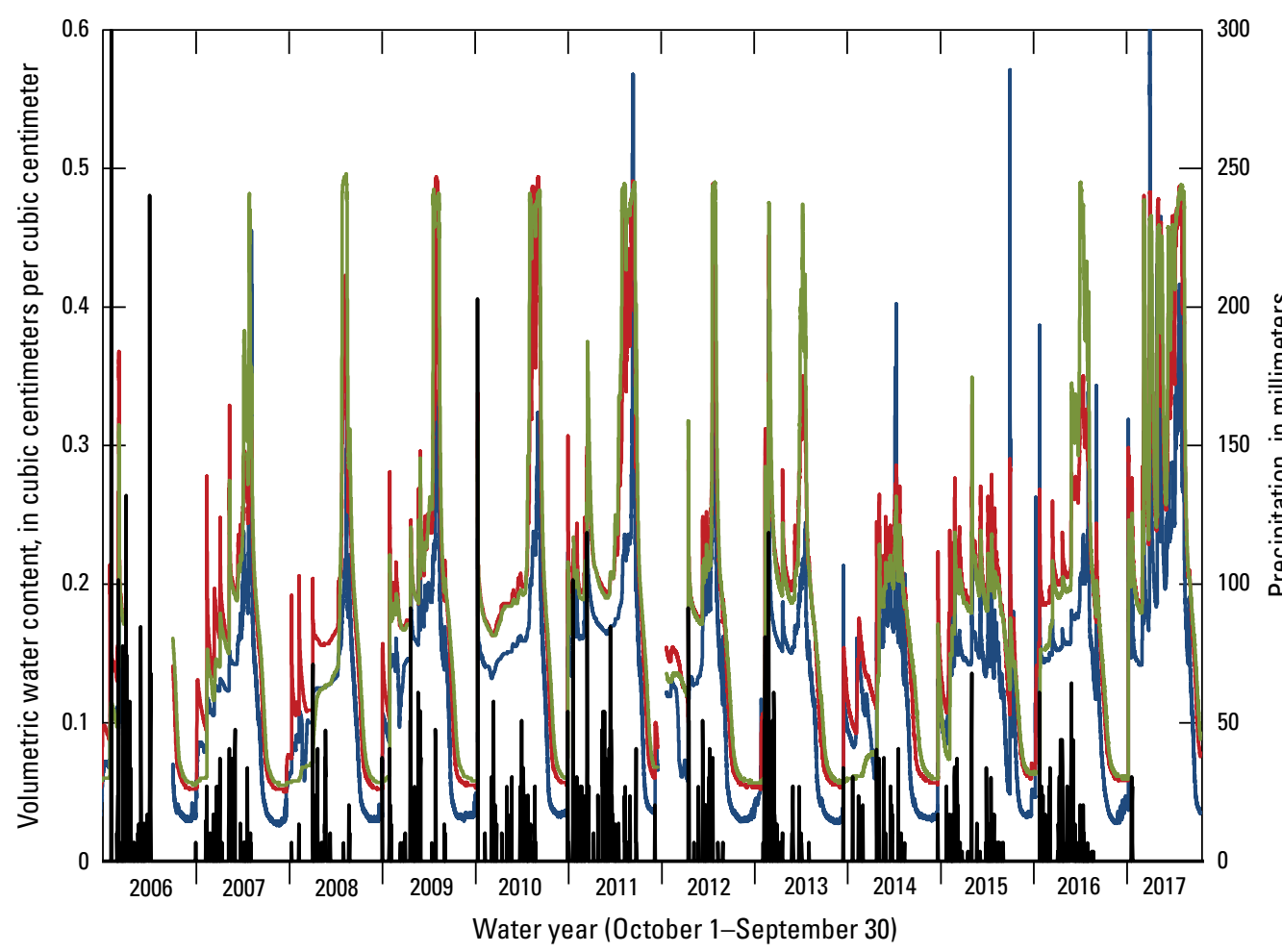

EXPLANATION

- 10 centimeters

- 36 centimeters

- 72 centimeters

- Precipitation

Figure 10. Volumetric soil water content for the Gin Flat site at three depths. Precipitation data from California Data Exchange Center, CDEC, https://cdec.water.ca.gov/. 


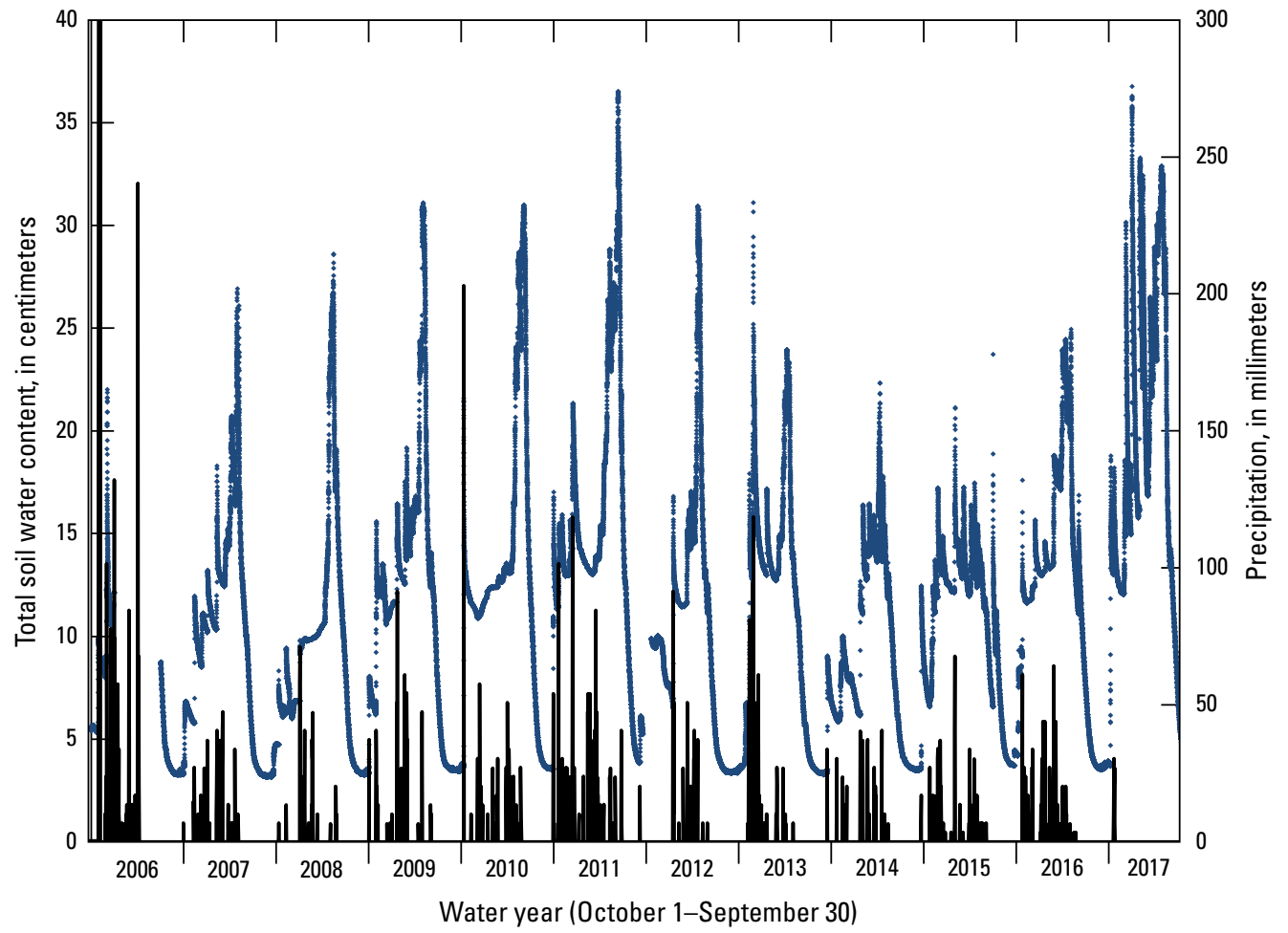

EXPLANATION

- Total soil water content

- Precipitation

Figure 11. Total soil water content for the Gin Flat site to a depth of 72 centimeters. Precipitation data from California Data Exchange Center, CDEC, https://cdec.water.ca.gov/.

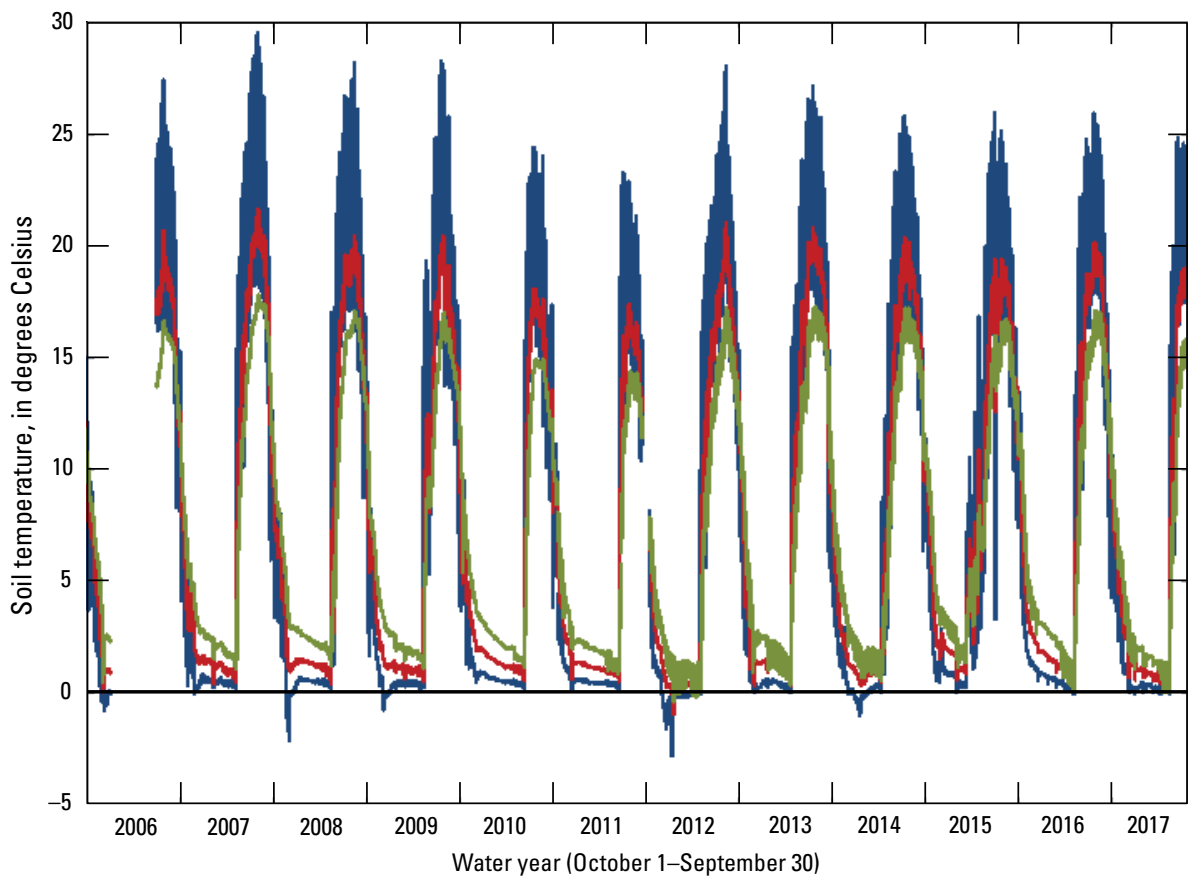

EXPLANATION

- 10 centimeters

36 centimeters

- 72 centimeters

Figure 12. Soil temperature for the Gin Flat site at three depths. 


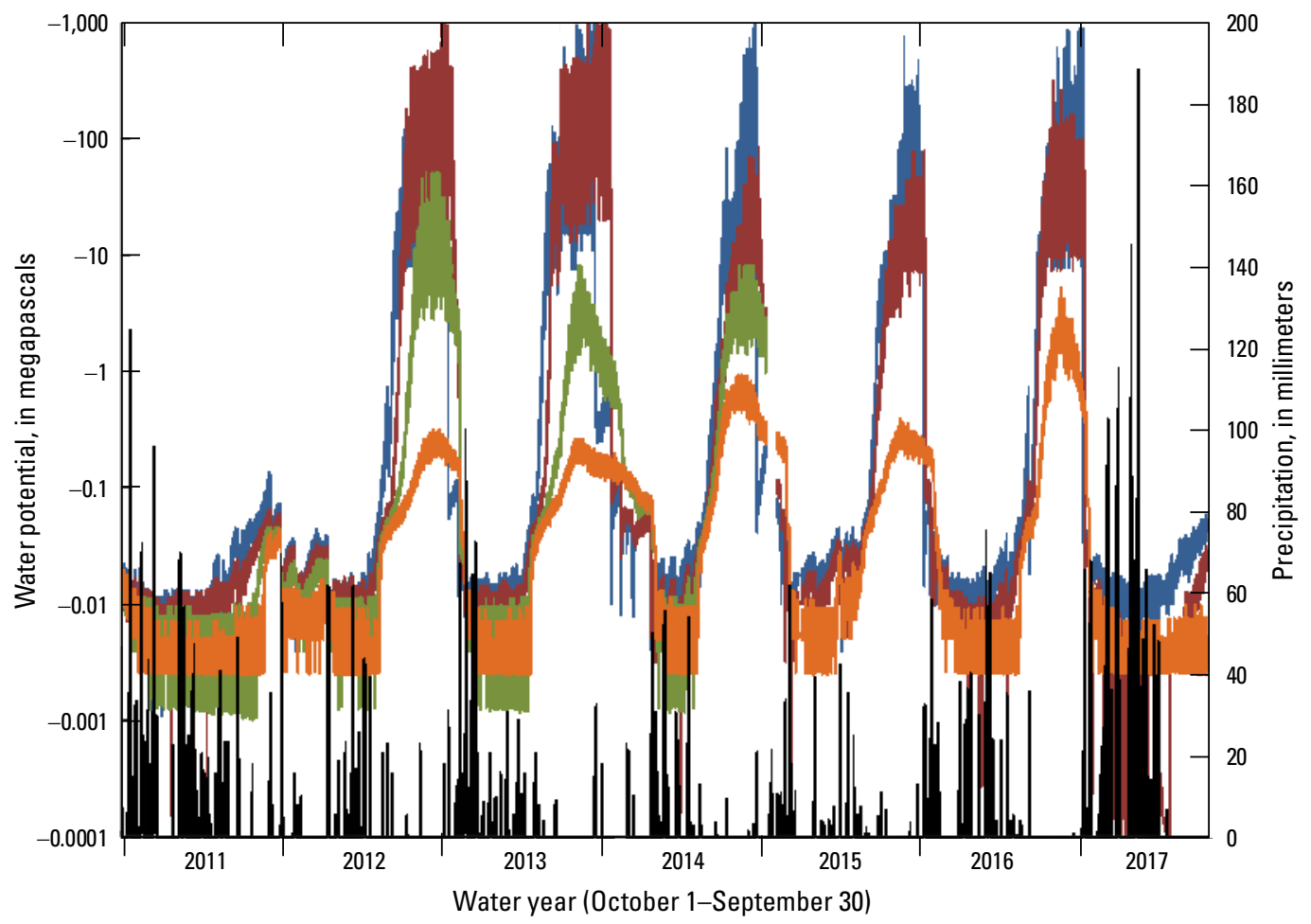

EXPLANATION

- 10 centimeters

- 25 centimeters

- 50 centimeters

— 80 centimeters

- Precipitation

Figure 13. Soil water matric potential for the Hodgdon Meadow site at four depths. Precipitation data from National Trends Network, NTN, http://nadp.sws.uiuc.edu/ntn/.

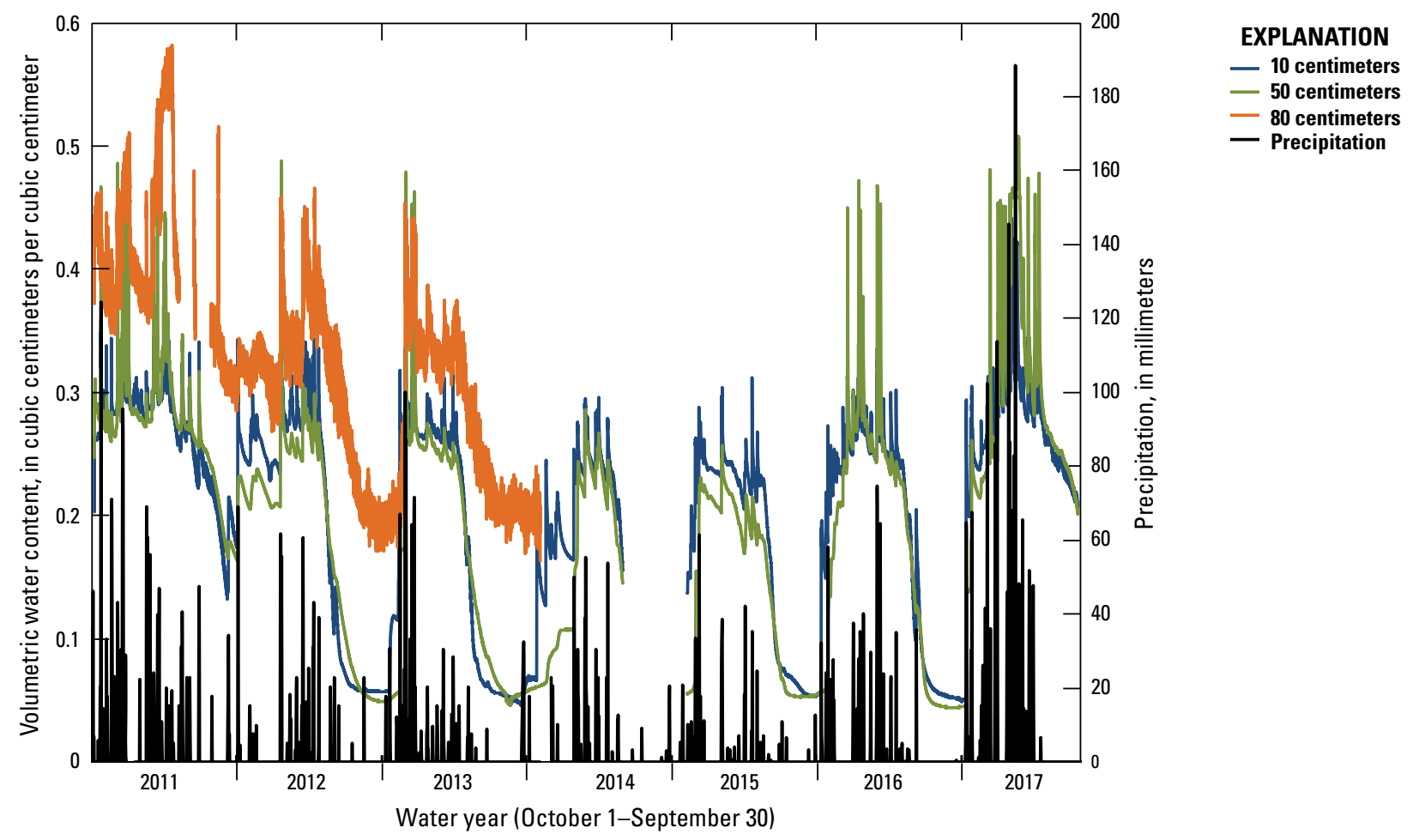

Figure 14. Volumetric soil water content for the Hodgdon Meadow site at three depths. Precipitation data from National Trends Network, NTN, http://nadp.sws.uiuc.edu/ntn/. 


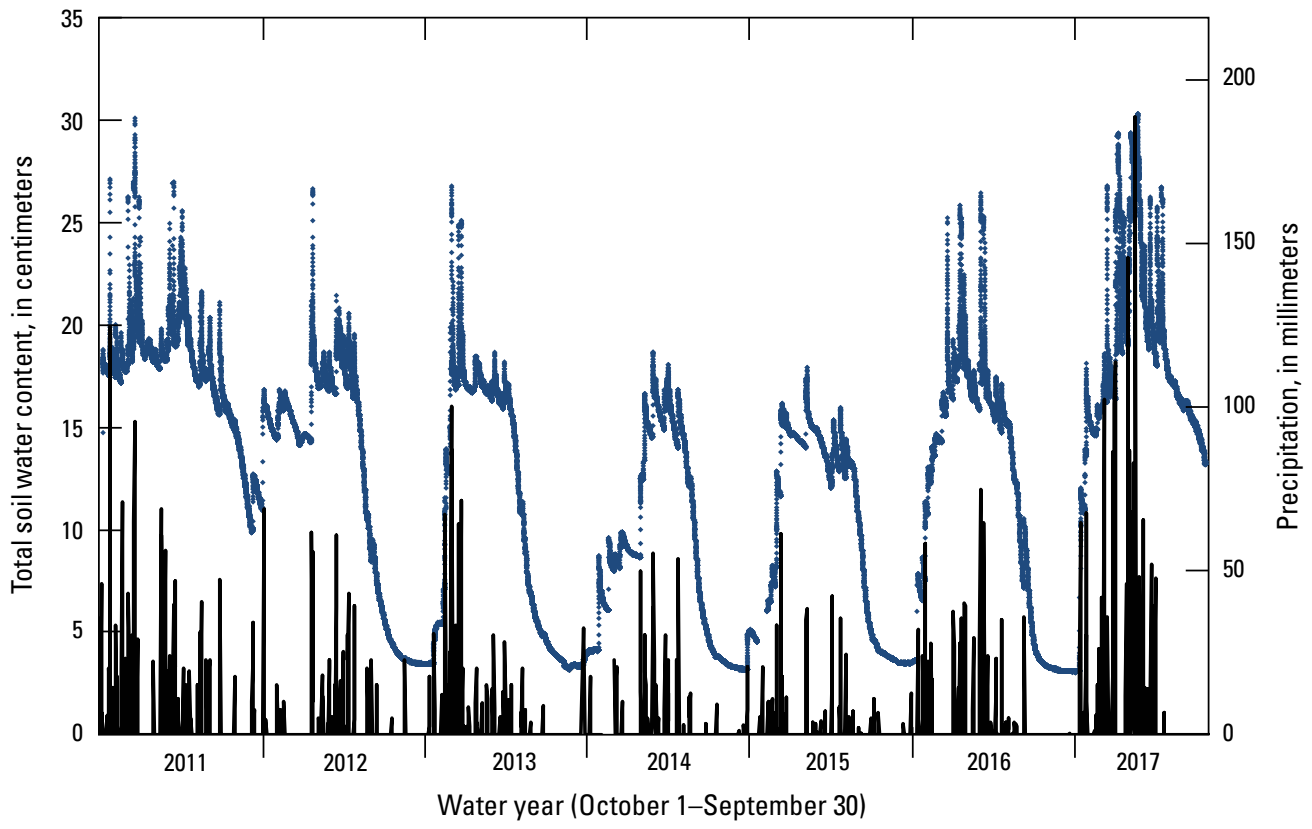

EXPLANATION

- Total soil water content

- Precipitation

Network, NTN, http://nadp.sws.uiuc.edu/ntn/.

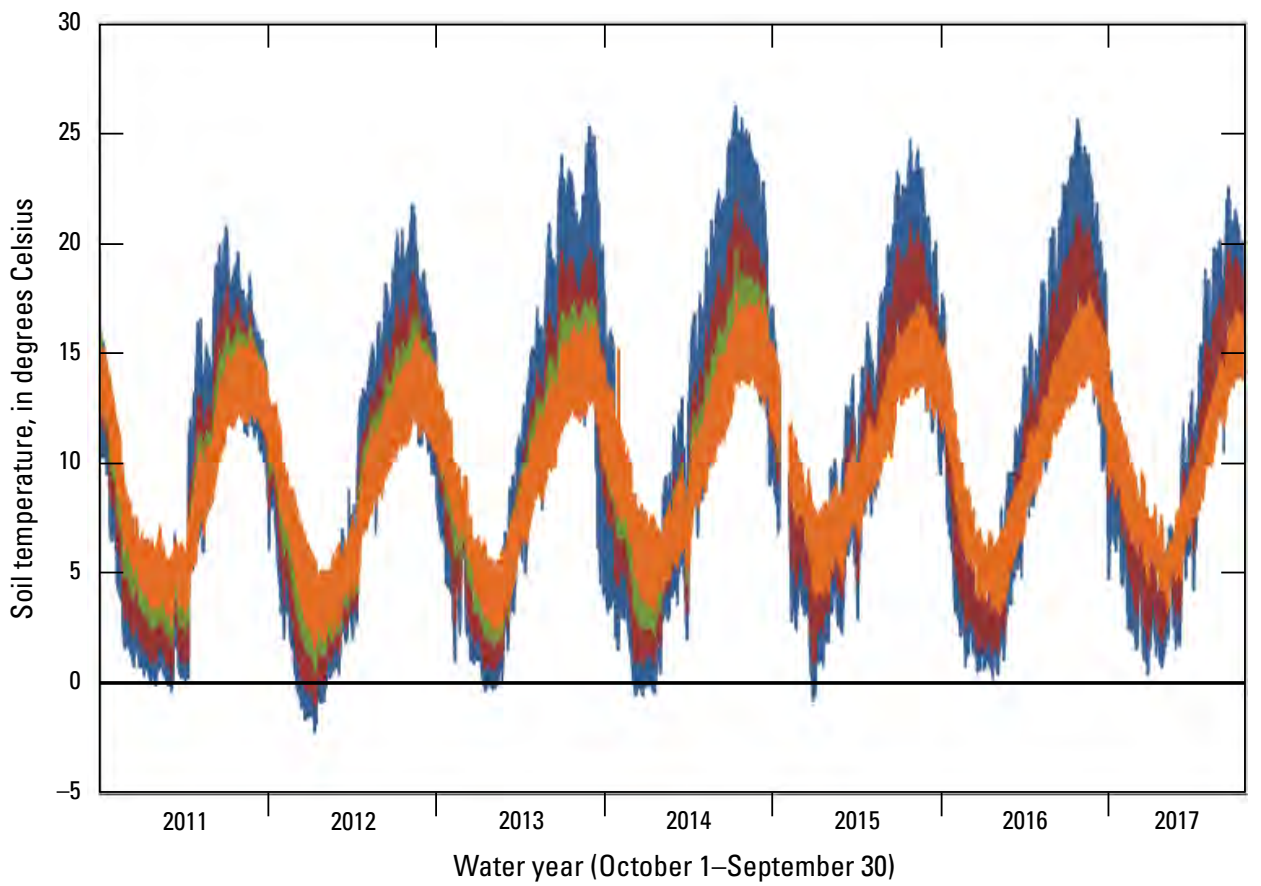

Figure 16. Soil temperature for the Hodgdon Meadow site at four depths. 


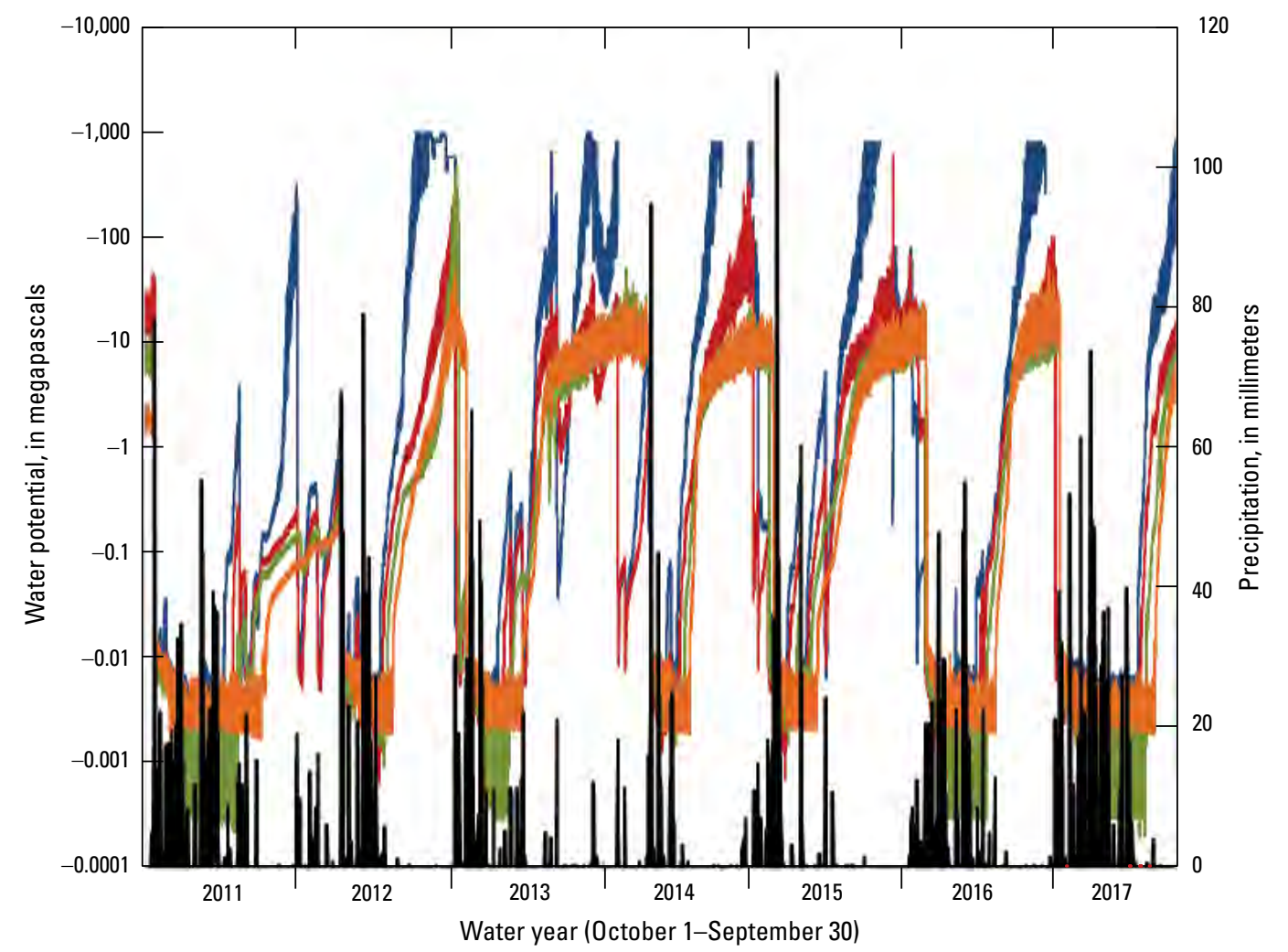

EXPLANATION

- 15 centimeters

- 30 centimeters

- 60 centimeters

- 90 centimeters

- Precipitation

Figure 17. Soil water matric potential for the Pepperwood Preserve Grass site at four depths.

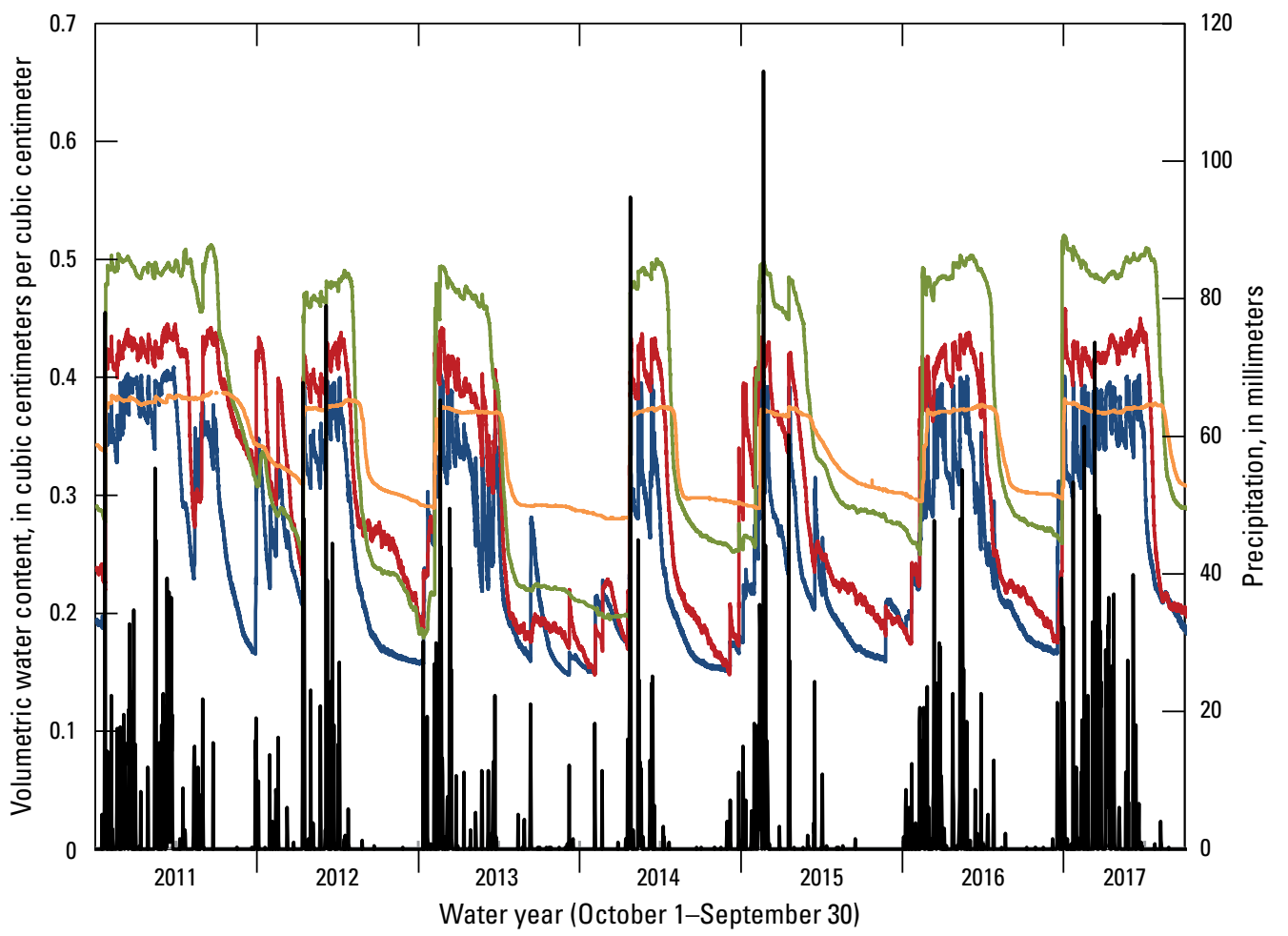

Figure 18. Volumetric soil water content for the Pepperwood Preserve Grass site at four depths. 


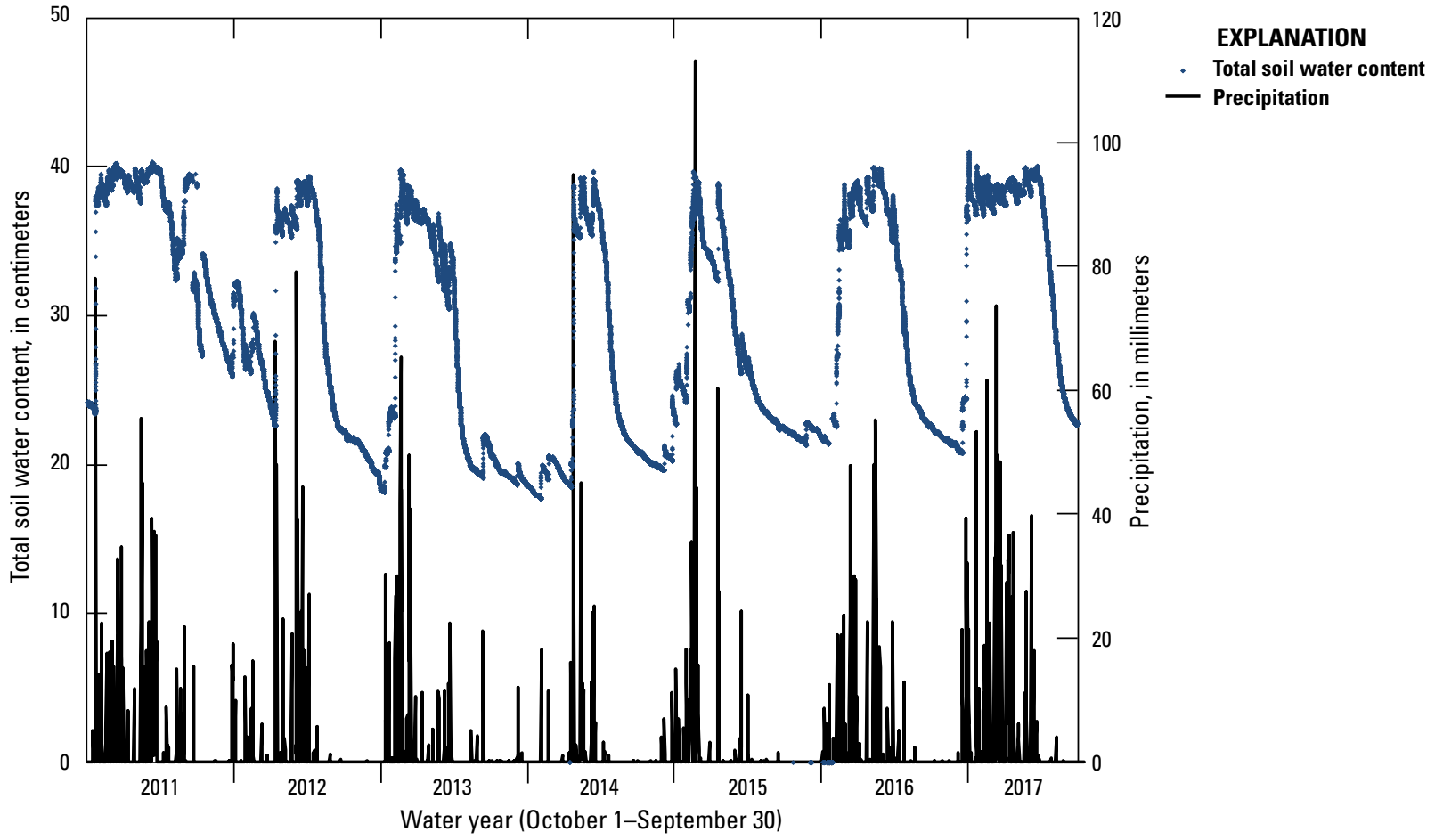

Figure 19. Total soil water content for the Pepperwood Preserve Grass site to the depth of 90 centimeters.

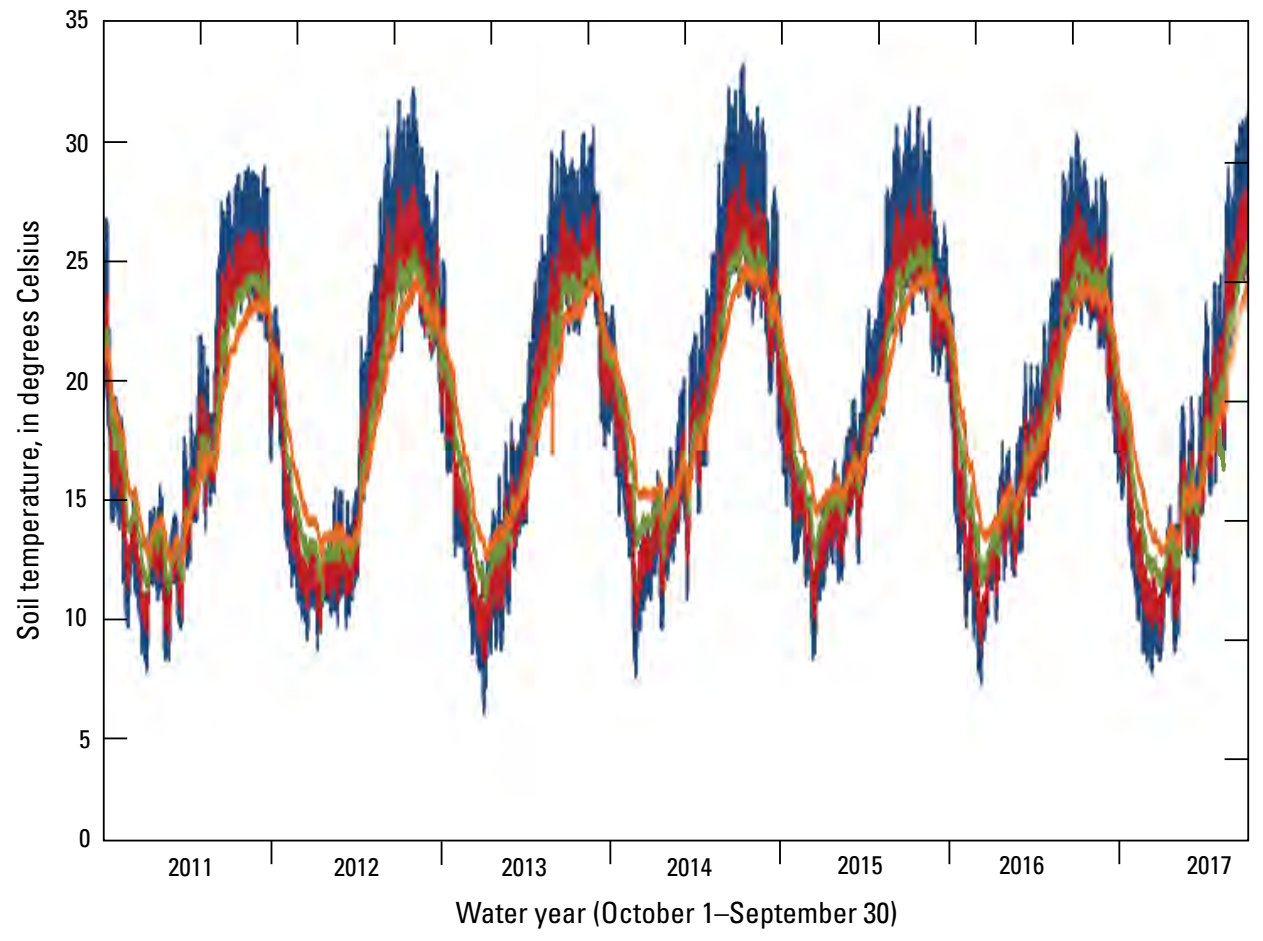

Figure 20. Soil temperature for the Pepperwood Preserve Grass site at four depths. 


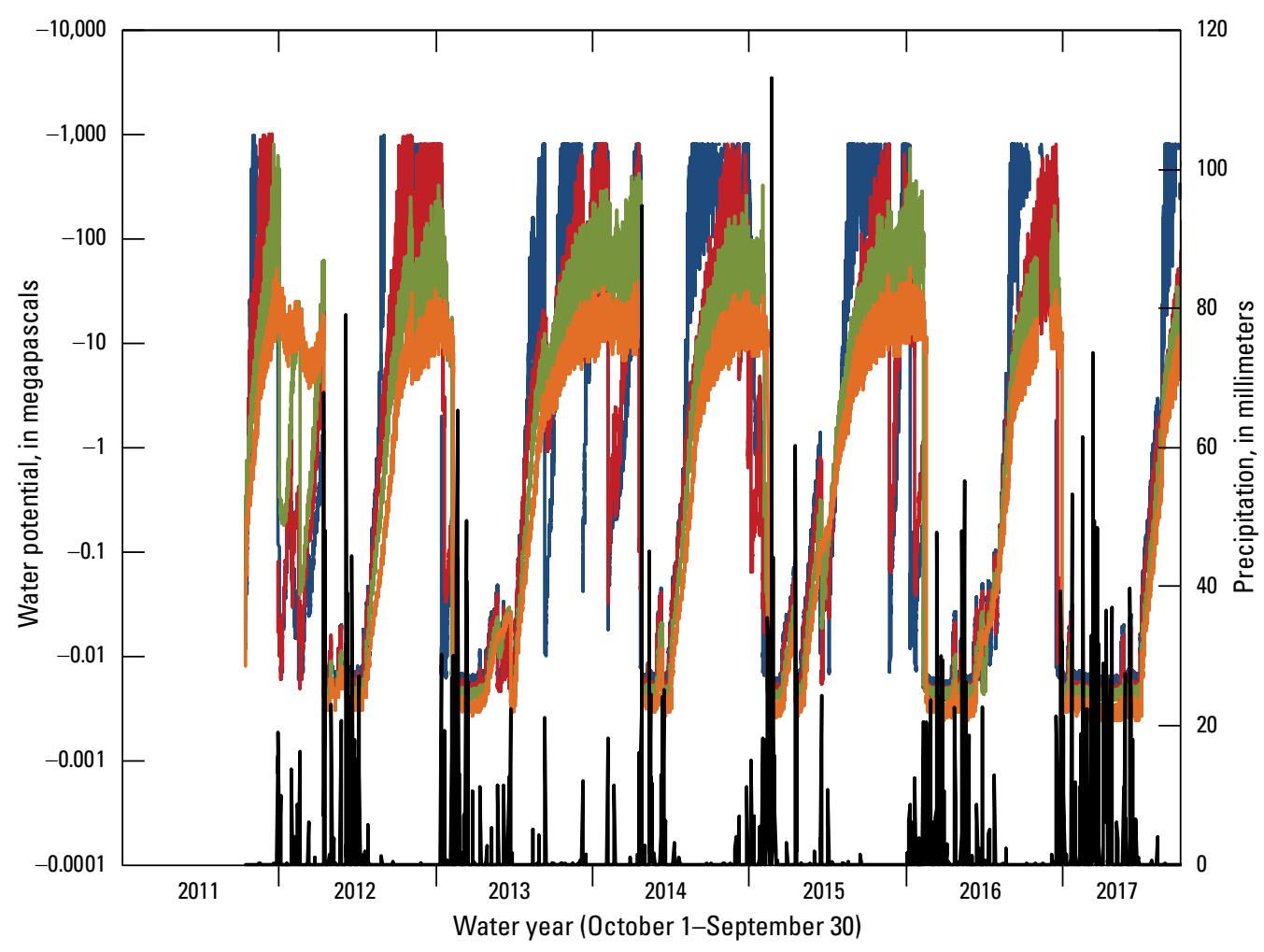

EXPLANATION

- 5 centimeters

- 20 centimeters

- 45 centimeters

- 70 centimeters

- Precipitation

Figure 21. Soil water matric potential for the Pepperwood Preserve Oak site at four depths.

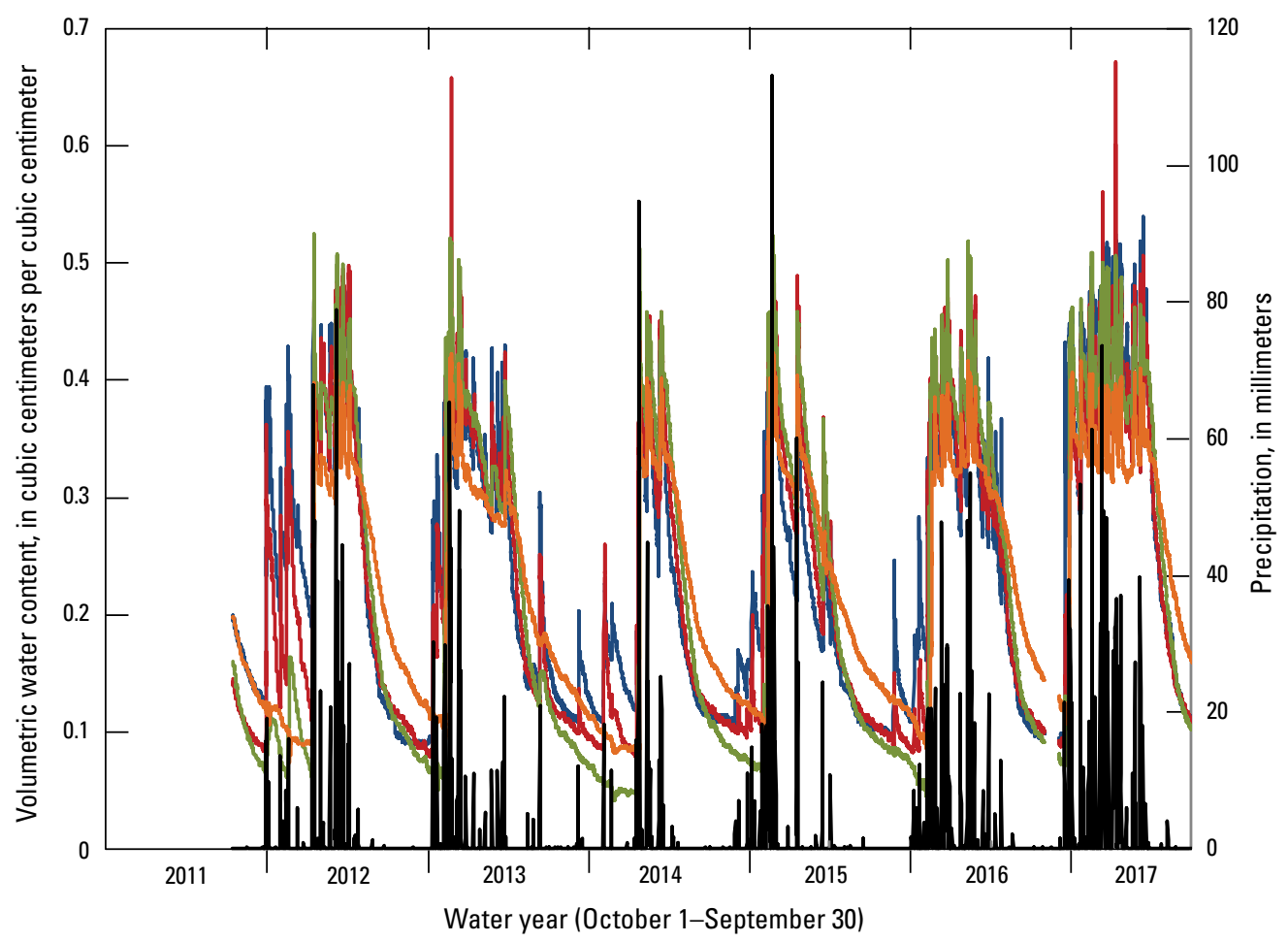

- 45 centimeters

- 70 centimeters

- Precipitation

Figure 22. Volumetric soil water content for the Pepperwood Preserve Oak site at four depths. 


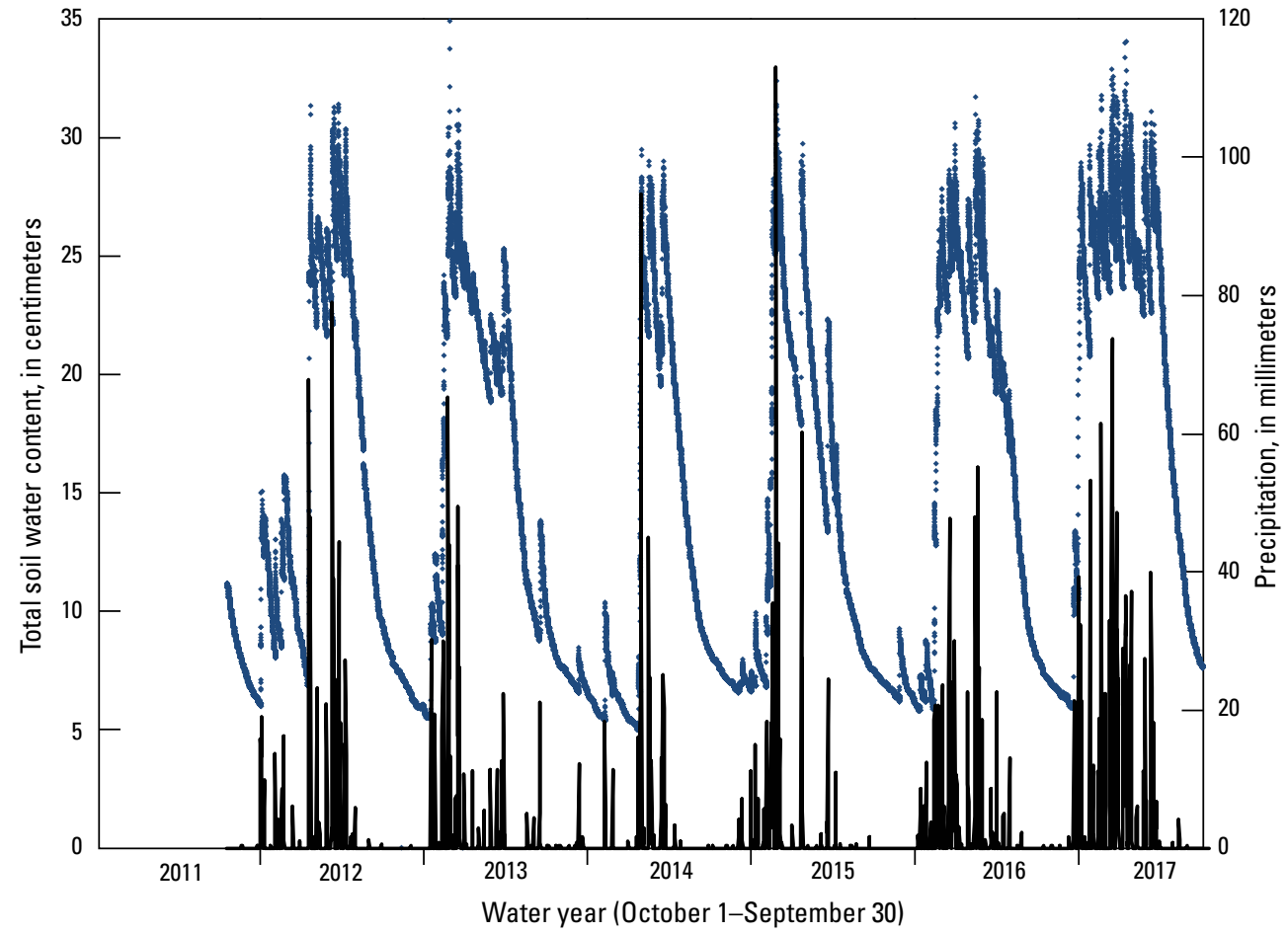

Figure 23. Total soil water content for the Pepperwood Preserve 0ak site to the depth of 70 centimeters.

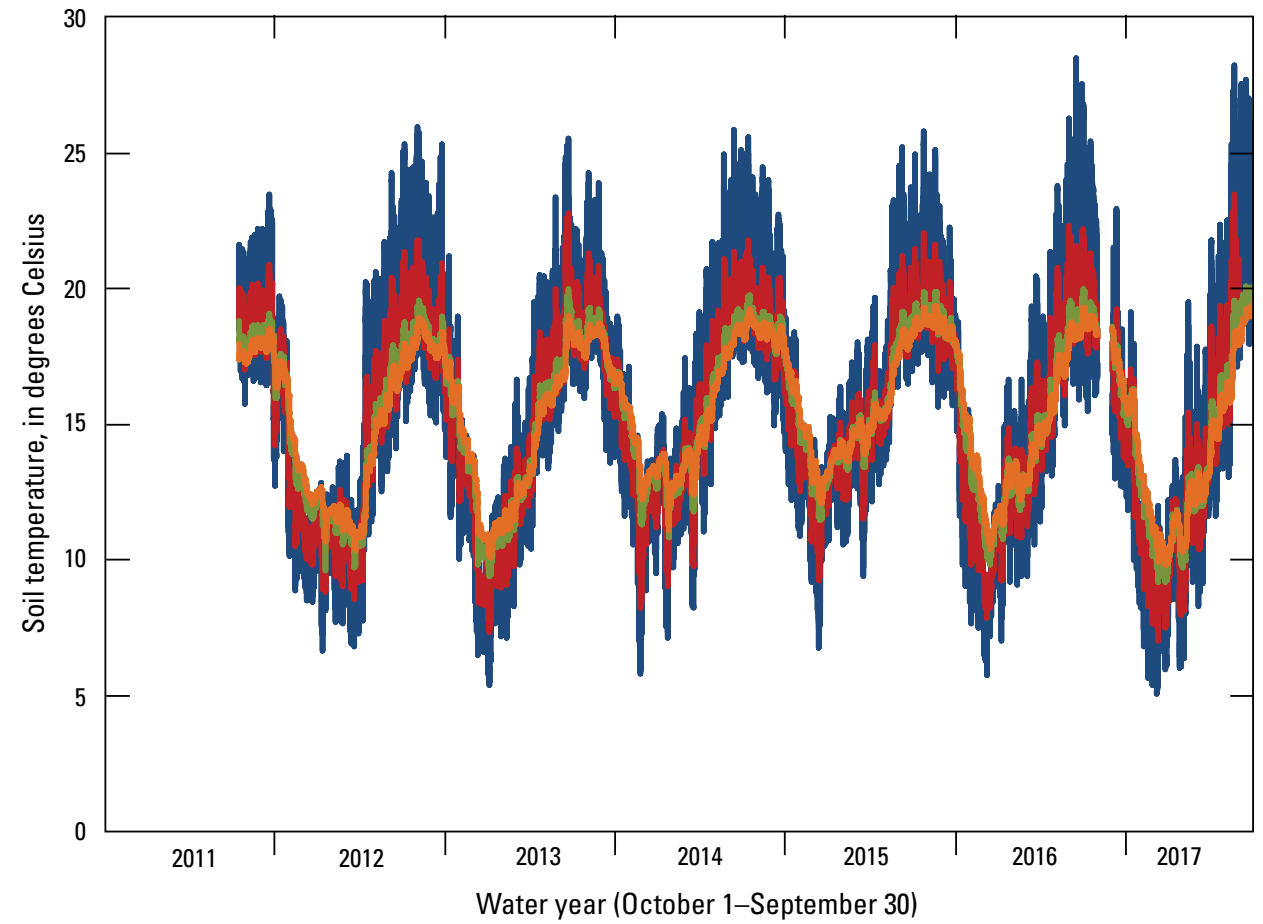

Figure 24. Soil temperature for the Pepperwood Preserve Oak site at four depths. 


\section{Future Work}

Data collection from the five sites is ongoing, but any future updates to this report and dataset are subject to funding limitations. Long-term soil datasets like the one described in this report are valuable for hydrologic modeling and understanding soil-water processes in differing climate, soil, and geology (Western and others, 2002; Flint and others, 2008), and these data are useful for numerous multidisciplinary studies.

\section{Summary}

In situ soil moisture datasets are important inputs used to calibrate and validate watershed, regional, or statewide modeled and satellite-based soil moisture estimates. The soil moisture dataset described in this report includes hourly series of the following: soil temperature, volumetric water content, soil water matric potential, and total soil water content. Data were collected by the U.S. Geological Survey (USGS) in cooperation with the Department of Water Resources at five locations in California: three sites in the central Sierra Nevada and two sites in the northern Coast Ranges. The two study areas represent geologic and hydroclimatic contrasts that were selected for the purpose of understanding hydrologic, climatic, and biologic soil moisture dynamics in snow-dominated watersheds and coastal fog-dominated watersheds. These sites extend beyond the surficial soil layer to bedrock or near bedrock when possible, which better characterizes the soil profile and thus the soil response to climate.

\section{References Cited}

Bales, R.C., Molotch, N.P., Painter, T.H., Dettinger, M.D., Rice, Robert, and Dozier, Jeff, 2006, Mountain hydrology of the western United States: Water Resources Research, v. 42, 13 p., accessed July 2, 2014, at https://doi.org/10.1029/2005WR004387.

Campbell Scientific, Inc., 1996, CS615 Water content reflectometer: Logan, Utah, Campbell Scientific, Inc., $18 \mathrm{p}$., available at https://s.campbellsci.com/documents/au/manuals/cs615.pdf.

Campbell Scientific, Inc., 2009, 229 Heat dissipation matric water potential sensor manual: Campbell Scientific, Inc., 28 p., available at http://s.campbellsci.com/documents/cr/manuals/229.pdf.

Campbell Scientific, Inc., 2016a, CS616 and CS625 Water content reflectometers: Campbell Scientific, Inc., 46 p., available at https://s.campbellsci.com/documents/us/ manuals/cs616.pdf.

Campbell Scientific, Inc., 2016b, TE525 Tipping bucket rain gage: Campbell Scientific, Inc., 30 p., available at https://s.campbellsci.com/documents/us/manuals/te525.pdf.

Decagon Devices, Inc., 2008, $\mathrm{ECH}_{2} \mathrm{O}-\mathrm{TE} / \mathrm{EC}-\mathrm{TM}$ Water content, EC and temperature sensors, operator's manual, ver. 7: Pullman, Wash., Decagon Devices, Inc., 39 p., available at http://www.decagon.com.br/assets/Manuals/ ECH2O-TEEC-TMv6.pdf.]

de Nevers, Greg, 2013, Vascular flora (3d ed.): Santa Rosa, Calif., Pepperwood Foundation, 98 p., available at http://www.pepperwoodpreserve.org/wp-content/ uploads/2016/03/Pepperwood-Preserve-Vascular-FloraThird-Edition-16-01-14.pdf.

Flint, A.L., Campbell, G.S., Ellett, K.M., and Calissendorff, C., 2002, Calibration and temperature correction of heat dissipation matric potential sensors: Soil Science Society of America Journal, v. 66, p. 1439-1445. 
Flint, A.L., Flint, L.E., and Dettinger, M.D., 2008, Modeling soil moisture processes and recharge under a melting snowpack: Vadose Zone Journal, v. 7, no. 1, p. 350-357.

Keeler-Wolf, T., Moore, P.E., Reyes, E.T., Menke, J.M., Johnson, D.N., and Karavidas, D.L., 2012, Yosemite National Park vegetation classification and mapping project report: National Park Service, Natural Resource Technical Report NPS/YOSE/NRTR—2012/598, 737 p., available at https://irma.nps.gov/DataStore/DownloadFile/452135.

Klinger, R., Underwood, E.C., and Moore, P.E., 2006, The role of environmental gradients in non-native plant invasion into burnt areas of Yosemite National Park, California: Diversity and Distributions, v. 12, p. 139-156.

Lutz, J.A., van Wagtendonk, J.W., and Franklin, J.F., 2010, Climatic water deficit, tree species ranges, and climate change in Yosemite National Park: Journal of Biogeography, v. 37, p. $936-950$.

McLaughlin, R.J., Sarna-Wojcicki, A.M., Fleck, R.J., Wright, W.H., Levin, V.R.G., and Valin, Z.C., 2004, Geology, tephrochronology, radiometric ages, and cross sections of the Mark West Springs 7.5' quadrangle, Sonoma and Napa Counties, California: U.S. Geological Survey Scientific Investigations Map 2858, scale 1:24,000, 16 p., https://pubs.usgs.gov/sim/2004/2858/.

McMahon, P.B., Dennehy, K.F., Michel, R.L., Sophocleous, M.A., Ellet, K.M., and Hurlbut, D.B., 2003, Water movement through thick unsaturated zones overlying the central High Plains aquifer, southwestern Kansas, 2000-2001: U.S. Geological Survey Water-Resources Investigations Report 03-4171, 32 p., https://pubs.usgs.gov/wri/wrir03-4171/.

van Genuchten, M.T., 1980, A closed-form equation for predicting the hydraulic conductivity of unsaturated soils: Soil Science Society of America, v. 44, no. 5, p. 892-898.

Western, A.W., Grayson, R.B., and Bloschl, Gunter, 2002, Scaling of soil moisture-A hydrologic perspective: Annual Review of Earth and Planetary Sciences, v. 30, p. 149-180. 

Publishing support provided by the U.S. Geological Survey Science Publishing Network, Sacramento Publishing Service Center

For more information concerning the research in this report, contact the Director, California Water Science Center U.S. Geological Survey $6000 \mathrm{~J}$ Street, Placer Hall Sacramento, California 95819 https://ca.water.usgs.gov 


\section{$\frac{\mathbb{2}}{3}$}

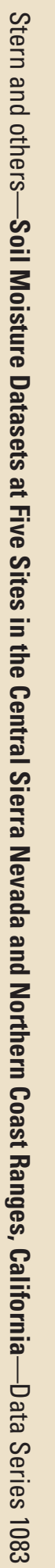

ISSN 2327-638X (online)

https://doi.org/10.3133/ds1083 